\title{
THE REQUIREMENT OF OPPORTUNITY TO BE HEARD IN THE ADMINISTRATIVE PROCESS
}

\author{
KENNETH CULP DAVIS $\uparrow$
}

THE purpose of a hearing in the administrative process is to assure enlightened administrative action which safeguards affected interests by taking into account both information and persuasion which those interests can supply and by subjecting the materials on which the agency acts to the parties' testing processes. The criteria for determining when opportunity for hearing should be required must be sought by inquiring into the practical means by which that purpose may best be achieved. This paper is the product of a search for those criteria. ${ }^{1}$

The terms "hearing" and "opportunity to be heard" probably convey the same core of meaning to most minds, but their fringe of uncertainty is wide. I believe that when either judges or legislatures use the term "opportunity to be heard" they have in mind one of two ideas: (1) a chance to present argument at a public meeting, or (2) opportunity for a trial resembling that of the courtroom. ${ }^{2}$ The term as commonly used does not mean talking informally to the man who decides, or submitting written evidence or argument without an oral process, ${ }^{3}$ or participating in a conference out of which a decision grows, or answering one

$\dagger$ Professor of Law, University of Texas Law School.

1. My inquiry is into the question when opportunity for hearing ought to be required. I shall not always carefully distinguish requirements imposed by judges in the name of a constitution from requirements imposed by legislatures or from requirements imposed by agencies upon themselves. They tend to merge. It is often observed that constitutional requirements should be kept to a minimum and that the agencies themselves should often follow higher standards than the judges require. I can agree only with some reservation; I wonder how much weight should be given to an agency's natural tendency to interpret a court's refusal to find a denial of due process as judicial approval of what the agency has done, with the practical result that the agency's practice coincides with the constitutional minimum. There are many signs that this tendency is especially pronounced among some state agencies.

2. The Attorney General's Committee on Administrative Procedure uses the term "adversary hearing" for what I call trial. See Rep. Arr'y Gev. Coss. Ap. Proc. (1941) 10S. [Hereinafter cited as REPORT (1941)]. The term "adversary", I thinl, is best uscd to indicate opposing parties, and parties may oppose each other at speech-making hearings in which trial methods are not used. An argument to an appellate court is adversary, but it is not a trial.

3. Compare Londoner v. Denver, 210 U. S. 373,386 (1908): "If it is enough that, under such circumstances, an opportunity is given to submit in writing all objections to and complaints of the tax to the board, then there was a hearing afiorded in the ease at bar. But we think that something more than that, cven in preceedings for tasation, is required by due process of law. . . . A hearing in its very essence demands that he who is entitled to it shall have the right to support his allegations by argument howerer brief, and, if need be, by proof, however informal." 
of the questionnaires which provide the entire factual basis for the decision, or receiving a tentative draft of proposed rules with an invitation to submit written comments, or sending a representative to collaborate with the agency's staff in drafting regulations, or participating in the selection of an advisory group which may make recommendations to the agency, or answering oral questions asked by the agency's interviewers. I doubt if the term as generally employed would include inspecting all the data collected by the agency and submitting comments or evidence informally. And when, for instance, labor organizations and employers appoint representatives to serve along with public representatives on a board which has power to decide, I doubt if that much alone would be considered opportunity to be heard. ${ }^{4}$

Of course, a single proceeding may be hybrid, with varying proportions of the speech-making method and of the trial method. ${ }^{5}$ But it is nevertheless convenient for discussion to treat the two methods as distinct. A speech-making hearing, often called a public meeting, is normally governed by no more rules than are essential for orderly presentation of arguments. The trial technique draws heavily from complexities evolved in the judicial system. The essential characteristics of the method of trial are: (1) requiring the findings to be based upon evidence in a formal record of the proceedings, except to the extent that official notice is appropriate, and (2) giving each party, within wide limits, full rights of cross-examination and rebuttal, as well as the right to offer affirmative proof. Although the oath is usually required and specific findings are often necessary, probably neither of these elements should be regarded as among the essential characteristics of a trial.

Other Devices as Substitutes for Hearings. For some types of business the objective of assuring enlightened administrative action which properly safeguards affected interests is better attained by devices other than hearings, for a trial may be obviously inappropriate and a public meeting may not afford adequate safeguards.

When technicians of shipping companies collaborated with technicians of the Bureau of Marine Inspection and Navigation in preparing elab-

4. Both the National Railroad Adjustment Board and the now abolished National Defense Mediation Board are suggestive in this connection. Att'y Gen. Comm. Ad. Proc., The National Railroad Adjustment Board, SEn. Doc. No. 10, Pt. 4, 77th Cong., 1st Sess. (1941); Jaffe and Rice, Report on the Work of the National Defense Mediation Board (1942) (mimeographed).

5. A typical legislative committee hearing is hybrid. It is not a trial; the committee decides on all the information it has, whether in a formal record or not, and private parties usually are not given the privilege of cross-examination. The hearing is mostly a speech-making hearing, with cross-examination by committee members and by the committee's counsel. 
orate regulations governing tanker vessels, including detailed specifications for construction, the companies got far better protection for their interests than any kind of a hearing could have afforded. ${ }^{6}$

In formulating regulations governing transportation of household goods by motor carriers the ICC conducted $\$ 9$ informal conferences attended by 1,740 individuals representing 1,286 carriers, and then submitted questionnaires, 2,631 of which were analyzed and digested by the Commission's staff. The later hearings were probably relatively unimportant either as sources of information or as means of understanding points of view. ${ }^{7}$

The Attorney General's Committee, in the budy of its report, admiringly described methods of the Board of Governors of the Federal Reserve System: "The practice of the Board . . . is especially noteworthy because of the Board's virtually complete reliance upon conferences rather than hearings as a means of enabling affected parties to participate in the rule-making process. Over a period of time the Federal Reserve System has developed a procedure of consultation and conference. . . . Outside views come from replies to letters which the Board sends out, and orally at conferences. Usually statements are put in writing and a stenographic report of conferences is made. Frequently, the interchange of data and views is facilitated by mimeographing and circulating them, both within and without the staff. The procedure is flexible, thorough, adapted to bringing the lnowledge of an expert agency to bear upon its rule-making problems, and fair . . ."8

In the preparation of insurance regulations for motor carriers, a representative of the ICC travelled through fifteen states to interview representatives of motor carriers, members of state commissions, executives of insurance companies, and insurance agents and brokers. Later, conferences were held with committees representing the bus industry, the truck industry, and the insurance associations. Although the Commission held hearings on the proposed regulations, the preliminary interviews and conferences were probably more effective in protecting private interests. ${ }^{9}$

One of the most satisfactory means of safeguarding affected interests is to make copies of proposed rules available to those affected, and invite written comments. Depending on circumstances, later hearings may or

6. Att'y Gen. Comm. Ad. Proc, Defarlment of Cummerce, Burcull of Marine In:spection and Narigation, SEx. Doc. No. 186, Pt. 10, 7uth Cung., 3il Sess. (1940) 33. The monograph writer says flatly of this activity: "Public huarings as such have been largely empty forms, adding nothing to what is already known."

7. Att'y Gen. Comm. Ad. Proc, Interstute Commerce Commissiun, SE:t. Due. Su. 10, Pt. 11, 77th Cong., 1st Sess. (1941) 85-6.

8. Report (1941) 104.

9. Att'y Gen. Comm. Ad. Proc, Interstate Comancrec Commission, SE:.. Doc No. 10, Pt. 11, 77th Cong., 1st Sess. (1941) 85. 
may not be desirable. On some types of rules, a speech-making hearing preceding the drafting and promulgating of the rules provides far less practical protection than a procedure which includes questionnaires, interviews, and conferences, followed by submission of proposed rules for written comments.

Increasingly important is the representative board. For instance, the Emergency Price Control Act permits establishment of price ceilings without hearings, but requires that "before issuing any regulation or order . . . the Administrator shall, so far as practicable, advise and consult with the representative members of the industry," and that after a maximum price has been established, "the Administrator shall, at the request of any substantial portion of the industry . . . appoint an industry advisory committee . . . [and] shall from time to time, at the request of the committee, advise and consult with the committee . . . [which] may make such recommendations to the Administrator as it deems advisable." 10

Other devices which may supplement or supplant hearings are many and varied. One can find them in nearly every agency though they are seldom recognized in judicial opinions. ${ }^{11}$ They are often the lifeblood of enlightened and fair administrative action.

The problem of providing protection against uninformed or arbitrary action is thus sometimes broader than what is embraced in the idea of opportunity to be heard. Sometimes the vital question is not whether to require opportunity to be heard; the vital question may be: To what extent and in what way should parties affected by administrative action be permitted to participate in the process of formulating that action? The key may often be participation, not hearing. Sometimes to be preferred are collaboration in drafting, conferences, interviews, questionnaires, submission of proposed rules with invitations for written comments, consultations with representative boards, and other like devices, separately or in combination.

The criterion for determining what methods of participation should be allowed, and whether the methods of public speeches or trial are requisite, lies in a pragmatic answer to the question - what method will

10. Emergency Price Control Act of 1942, Pub. L. 421, 77th Cong., 2d Sess. (Jan. $30,942), \S 2(a)$.

11. The Attorney General's Committee on Administrative Procedure places great emphasis on the importance of the agencies' methods of investigation: "Where conferences and hearings are not held, the initial investigation is of all-embracing importance in the rule-making process. Where conferences and hearings are held after the investigatory stage has passed, they may or may not add to the information of the agency. Hence the initial investigation is of primary significance in most instances of rule-making. The methods by which it may be conducted are of great importance to affected private interests." REPORT (1941) 111-14. 
in the circumstances best achieve the objective of assuring enlightened action which will afford proper safeguards to affected interests? The test must be wholly practical.

The General Judicial Failure to Recognize Alternatize Devices. Not only do most of the judicial opinions regard opportunity for hearing or lack of it as the pivot on which fairness to the parties turns, but in deciding whether or not opportunity to be heard is necessary they tend to ignore the alternative devices. State ex rel. State Board of Mill: Control v. Nea'ark Milk Co ${ }^{12}$ is illustrative. One side asserted that the board fixed minimum milk prices " 'without an investigation by the control board of the milk industry and without notice to the defendant or opportunity afforded it to be heard'." 13 The other side claimed that the board "conducted an investigation" and acted only " "after careful consideration of the facts and proofs acquired in said investigation'." The court ignored this dispute about the alleged investigation. So far as the opinion reveals, the court had no interest whatsoever in the kind of investigation that might have been made. It held that "notice of proceedings before the subordinate body exercising, as here, the administrative function is not requisite to valid action by that body. Nor is a hearing required ..."1: I believe the court thus excluded from consideration one of the most important factors that should have entered into its decision. To allow the board to issue a price order without in any way securing information and an understanding of points of view from the producers and dealers seems highly questionable, if we assume our basic system of reliance upon courts to give content to the idea of procedural due process. But to permit the New Jersey board to issue a price order without either a trial or formal speeches at a public meeting might well be in keeping with the basic objective of assuring enlightened action and adequate safeguards for private interests. If the board's investigation included, as it may have, extensive consultations and conferences, permission to all concerned to examine accumulated data, invitations to parties to submit written evidence, submission of comprehensive questionnaires to producers and dealers, and publication of a tentative order for comment by parties before promulgation of the final order, the protection might have been superior to that provided by speech-making at a public meeting, or even better than a trial. At all events, the New Jersey court, in paying no attention to the board's investigation, ignored the essence of the problem.

12. 118 N. J. Eq. 504, 179 Atl. 116 (1935).

13. Id. at 522, 179 Atl. at 125.

14. Ibid. 
The leading case of Commonwealth $v$. Sisson ${ }^{15}$ may be more nearly typical. A fish and game board ordered a mill owner to discontinue a practice of thirty years' standing of discharging sawdust into a stream. The mill "had been examined by the board" but a hearing was requested and denied. The court rejected the owner's contention that the order could properly be entered "only after the hearing of evidence." Of its own decision the court declared: "The practical result is that the defendants are forbidden to conduct their sawmill as they have conducted it for thirty years, by a board who have not heard evidence and have refused the defendants a hearing; that the action of the board is final, and that no compensation is due them. This result may seem strange

."16 I think it is strange indeed to uphold the order without in any way allowing the owner to try to persuade the board, with facts or argument, that it should not be entered, or that some other order would be preferable. But I think it would be just as strange to require a courtroom type of proceeding at which evidence is presented and subjected to cross-examination, with the decision limited to facts of record. To enter the order without consulting the owner is grossly unfair; to use a trial technique is clumsy and wasteful. Yet these are apparently the only alternatives the court considered, for it makes no mention of the owner's opportunities, or lack of them, for informally bringing its facts and arguments to the board's attention. The alternatives are not limited to requiring all — that is, a trial - or nothing. If the decision means that the board may, without prior knowledge of the owner, suddenly issue the final order, I find the decision shocking. If, on the other hand, it means that the board may investigate the fish and the stream and the sawdust and alternative disposal methods, submit its findings to the owner, invite the owner to suggest reasons for some different solution of the problem, and then enter the order without resort to trial, I regard the decision as sensible. But in the opinion as rendered, the crucial considerations are missing.

$M c G r e w$ v. Industrial Commission ${ }^{17}$ illustrates another deserving device which is often beyond the range of judicial vision. The Utah Commission had an assignment which required nothing less than finding, inter alia, what wage for women and minors was adequate "to supply the cost of proper living." The legislature did not pretend that that was a mere matter of taking evidence and finding facts, but sensibly provided for a wage board of equal numbers of employees and employers with a member of the commission as chairman, the board to investigate, find facts, and make recommendations to the commission, which would

15. 189 Mass. 247,75 N. E. 619 (1905).

16. Id. at $253,75 \mathrm{~N}$. E. at 622 .

17. 96 Utah 203,85 P. (2d) 608 (1938). 
then hold "public hearings" and issue its order. The court perfunctorily recited the provision for the wage board and then apparently forgot it. The Commission held what the court called a "public meeting" at which proponents and opponents of the recommended order were allotted three hours each to talk. No witnesses were sworn, and no record was prepared. The court said it was "a case of 'we should' or "we should not' instead of a presentation of facts on the questions up for hearing." Without distinguishing between statutory and constitutional requirements, the court held: "The legislature in requiring a full and public hearing had regard to judicial standards . . . which are the essence of due process in a proceeding of a judicial nature."18 Now, I submit that the Utah legislature's judgment was better than the court's. Finding what wage is adequate to proper living does not call merely for proof with evidence, but for practical methods of adjusting wages to satisfy both employer and labor groups. The proper tools are not testimony and cross-examination but negotiation and bargaining and mediation. A board composed of equal numbers of employers and employees with a member of the commission as chairman is a good device for that purpose. Let each faction of the board dig up its facts and convince the opposing faction, with the chairman as mediator; let them thresh out the problem until they compromise or until they find compromise impossible and make a report by a majority of which the chairman is the decisive member. Then let the commission approve, if it chooses, and have the public come in and make speeches for and against the recommendation. ${ }^{19}$ That is one good way to fix a wage. It is a democratic process; it does not falsely pretend to be a scientific process. The court's virtual disregard of the function of the wage board seems to me, once again, to ignore the essence. ${ }^{20}$

18. Id. at $225,85 \mathrm{P} .(2 \mathrm{~d})$ at 618 .

19. As another objectionable aspect of the IIcGrew case, witness the following: “. . The record contains perhaps 200 letters to the Commission from diverse parties urging or opposing the action taken. While the Commission filed them and certifica them to us along with the record, most of them are in no sense evidence and we conclude that the Commission did not consider them and was not influenced thereby." Id. at 224, 85 P. (2d) at 617. The court, thinking the Commission was trying a case, did nut realize that letter-writing might be one of the most valuable means by which the Commission could learn the views of those concerned, and that, unlike the trial of a cass, thuse views ought to enter into the choice to be made. The process of rule-maling should to democratic, not undemocratic.

20. Contrast the $31 c G r i w$ case with Ray v. Parker, 15 Cal. (2d) 275, 101 P. (2d) 665 (1940), holding that due process requirements were met where a flan involving milk price fixing was formulated through a democratic process in which produsers participated, and where the plan was adopted after a public meeting but without a trial. 
Inappropriateness of Trial Technique for Helping Tribunal Makc Choices of Laze and Policy. A few elementary principles are not always appreciated. The trial technique is designed for proof of disputed facts. Proof is different from persuasion. When the objective is to persuade, argument rather than evidence is called for. Persuasion may include presentation of facts, as in the Brandeis type of brief and the oral argument based upon it. Courts permit presentation of some facts as a part of argument, oral and written, and require other facts to be presented as evidence. The facts which concern the parties, their circumstances, their background conditions, the value of their property, who did what and why and when and how and with what motive or intent - these facts normally come in as evidence. Facts which do not peculiarly concern particular parties, facts which do not make up the gist of adjudication but help the tribunal to make choices of law or policy, as well as facts which are undisputed, may appropriately be presented to a court through written and oral argument rather than through evidence. The former in another context have been denominated adjudicative facts, and the latter legislative facts, and these terms are convenient though the lines are not precise. ${ }^{21}$

Since legislative facts generally may appropriately be presented to a court as a part of oral and written argument, it should follow that legislative facts may be presented to an administrative tribunal in the same way, that is, without use of the trial technique. Indeed, trial methods for presentation of ideas and arguments and legislative facts are often so clumsy and inefficient that one might expect any alert tribunal to assume as a matter of course that trial methods should normally be restricted to adjudicative facts. The following passage from a monograph on the ICC illustrates an extreme misuse of the trial technique:

... in the course of the hearings on safety regulations a witness was offered who was duly identified and qualified at some length. Finally the witness was asked if he had recommendations to make concerning the proposed regulations which the Commission had distributed. In the transcript appears the following:

A. We have a statement we would like to submit.

Q. And is that statement in writing?

A. It is.

Commissioner ........ Do you offer this for the record?

A. Yes; if the Commissioner please, if there is no objection,

I would like to ask at this time that it be received as an exhibit. Commissioner ......... Any objection? [No response].

It will be received and marked as "Exhibit 13."

21. Davis, An Approach to Problems of Evidence in the Administrative Process (1942) 55 Harv. L. Rev. 364, 402 et seq. 
Exhibit 13 is entitled "Statement by ........ on behalf of the Truck Owners Association of California." After identifying the association it declares: "We desire to make the following recommendations." Then follow various suggestions referring to pages and sections of the proposed regulations. It is suggested, for example, that the minimum age of drivers ought to be 18 instead of 21. Suggestions are made that words should be inserted or changed or omitted at certain lines and pages of the proposed regulations. Nearly every paragraph begins with "It is suggested that" or "It is recommended that." No facts of consequence are presented which seem to make the oath desirable or make the formality of the presentation of the statement necessary. Throughout the record are colloquies of counsel about admissibility of evidence, motions to strike statements from the record, objections to permitting a witness to state what he believes but what he does not linow, and all that goes with the cumbersomeness and awkwardness of highly legalistic courtroom proceedings. The continual "May it please the court" of an attorney in one proceeding blended with all the other trimmings. Much cross-examination is conducted which appears to be wholly pointless and examining attorneys sometimes attempt to force witnesses to answer "yes" or "no" where the witness wants to make an explanatory statement. Numerous discussions appear to have been held off the record. MIuch of the evidence was of necessity in the nature of opinion evidence or argument and the record seems clearly to reveal that direct and cross-examination are nut the most facile methods for presentation of arguments.

By reason of all this formality at the hearing, there is a tendency throughout the proceeding to follow the forms of adjudication. The Commission does not seem to recognize that the process of rulemaking need not necessarily always conform to the practices which are customary in the exercise of the judicial function. Rule $3(k)$ of the safety regulations provides that a driver must (with certain exceptions) have ability to read and speak the English langunge. In its formal report the Commission states: "Item $3(\mathrm{k})$, relating to knowledge of the English language, is amply supported by the record." In another part of its formal opinion, the Commission declares: "There is testimony in the record to the effect that amber is inherently a more desirable color for front clearance lamps than green, owing to its acceptance as a 'caution' signal and to the pussibility of confusing a green clearance lamp with a 'go' signal." In the hours of service case are statements such as the following:

We are convinced, from a consideration of the evidence, that it is safer under adverse weather and traffic conditions for a driver to drive or operate a motor vehicle for 12 hours at a lower rate of speed than attempt to cover the same distance in 10 hours of driving at a higher speed. 
The expressions of opinion by witnesses are usually referred to as evidence and testimony, but in the hours of service case the Commission made the statement that -

practically all of the zeitnesses representing carriers of property contended that we should prescribe a rule which would permit at maximum of 12 hours . . [ [Italics supplied]. ${ }^{22}$

The Food and Drug Administration takes "evidence" from "witnesses" who "testify" on such questions as whether "Golden" should be permitted as a synonym for "Yellow" in the labeling of canned corn, whether "Evaporated Milk" and "Concentrated Milk" should be used as synonyms, whether pear halves should have a minimum weight of $4 / 5$ ounces or $3 / 5$ ounces, whether tomato puree made from peelings and cores should be labeled "Trimmings" or "Tomato By-Products" or "Residual Tomato Material", whether peaches packed in a weak water solution must be labeled "In Water Slightly Sweetened" or may be labeled "In Light Syrup". ${ }^{23}$ At the hearings involving questions like these, any interested person may cross-examine any witness. Yet a careful commentator has observed that the primary value of the hearing is that it gives the Administrator "the benefit of criticisms and suggestions from representatives of the industries which will be affected, and from spokesmen for the consuming public." ${ }^{24}$ The problems lend themselves far better to written and oral argument than to testimony, cross-examination, and a decision on a formal record. The hearings now held are "unwieldy and sometimes almost chaotic" ${ }^{25}$ and consume weeks and even months. I think far better results would be obtained, with much

22. Att'y Gen. Comm. Ad. Proc., Interstate Commerce Commission, SEN. Doc. No. 10, Pt. 11, 77th Cong., 1st Sess. (1941) 86-7. The ICC, in its 1940 annual report refers to the monograph prepared for the Attorney General's Committee and declares at pages 19-20: "We have not been able to accept the suggestion in the monograph that many of our functions could be best performed by following the technique of investigation familiar in the practice of the committees of Congress, rather than by conducting hearings of a public character. We consider ourselves bound by the requirement of judicial decisions of our highest court defining the statutory terms 'hearing' and 'full hearing.' " I think this language of the Commission shows a fundamental misunderstanding of what is meant by "the technique of investigation familiar in the practice of committees of Congress." The Commission, I believe, should recognize the usefutness of public hearings which are not trials. To assume that every hearing must follow courtroom patterns is wasteful. Furthermore, I know of no "decisions of our highest court" which require trials for rule-making proceedings and other proceedings which involve primarily questions of interpretation or law or policy and do not involve conflicting evidence.

23. Heady, Administrative Rule-Making under Section 701(c) of the Food, Drug and Cosmetic Act (1942) 10 GEo. Wash. L. Rev. 406.

24. Id. at 444 .

25. Id. at 463 . 
less expense, through public meetings rather than trials. ${ }^{20}$ Unlimited cross-examination by adversaries is as inappropriate in these cases as it is in an argument before an appellate court. Cross-examination may be useful, but it should normally be conducted not by an adversary for the purpose of confusing and destroying but by the tribunal for the purpose of clarifying and constructing. Except in the unusual case in which disputes arise about specific primary facts, the oath and testimony are out of place; facts may be informally presented in a natural narrative form in briefs and arguments. Such simple and direct methods may lead the agency into deeper understanding of its problems than dozens of confused and confusing trials, with all their procedural rubbish, motions and objections and rulings and technicalities and exclusionary rules and the put-in-an-appearance-to-collect-a-fee type of lawyer. Of course, in the rare instances when specific facts are disputed, and testimony subject to cross-examination is appropriate, the tribunal may appropriately resort to a trial technique, carefully limiting the trial methods to discovery of the disputed facts.

The Federal Power Commission issued two sets of regulations providing uniform systems of accounts, one for electric companies and one for natural gas companies. After extensive studies and conferences had resulted in tentative drafts, hearings were held in both cases. In the first, informality prevailed, round table conferences were held, and speeches were made. In the second, the trial technique was used, witnesses gave sworn testimony, and parties were represented by counsel who formally introduced documentary evidence into the record and crossexamined opposing witnesses. The only reason for this strange use of the trial technique was the Commission's desire to satisfy "the most aggressive proponent of formalism" at a time when public clamor concerning administrative procedure was at its height. One observer wisely declares: "Now that the deed has been done, there appears to be no sentiment that the proceeding brought to light any information or opinions which could not have been obtained by much less wasteful and time-consuming methods." 27

Fixing of Rates, Prices, and Wages. The Supreme Court has flatly declared in a gas rate case: "We are concerned only with the question of procedural due process, that is, whether the Commission in its pro-

26. The responsibility for the clumsy methods apparently rests mostly with $\mathrm{Cun}_{\text {- }}$ gress, which has provided: "The Secretary shall base his order only on substantial evidence of record at the hearing . .. ." 52 ST.IT. 1040, 1055 (1938), 21 U. S. C., $\$ \$ 301$, 371 (1940). See Fuchs, The Formulation and Rezica of Regulations Untder the Fovd, Drug, and Cosmetic Act (1939) 6 Law \& Contearp. Prob. 43.

27. Att'y Gen. Comm. Ad. Proc, Federal Pauer Commission, SE:. Doc. Nó. 10, Pt. 12, 77th Cong., 1st Sess. (1941) 40. 
cedure . . . failed to satisfy the requirements of the Federal Constitution. We examine this question in the light of well settled principles governing the proceedings of rate-making commissions. The right to a fair and open hearing is one of the rudiments of fair play assured to every litigant by the Federal Constitution as a minimal requirement." 28 The first two Morgan cases $^{20}$ certainly demonstrate that an agency may fail to meet the requirements of "fair play" even when a trial technique is used in fixing rates. The Utah court has specifically held that a speechmaking or public-meeting type of hearing was insufficient for fixing minimum wages, ${ }^{30}$ and the Pennsylvania court has rendered a similar decision on fixing milk prices. ${ }^{31}$ In the recent $O p p$ case, ${ }^{82} \mathrm{Mr}$. Justice Stone characterized the proceedings before the Wage and Hour Administrator in a minimum-wage case as "judicial in character" 33 and declared: "The demands of due process do not require a hearing, at the initial stage or at any particular point or at more than one point in an administrative proceeding so long as the requisite hearing is held before the final order becomes effective." ${ }^{34}$ A discerning commentator finds in this language the implication that due process requires opportunity for hearing in a wage proceeding under the Fair Labor Standards Act. ${ }^{j 5}$

Nevertheless, despite these authorities, ${ }^{36}$ a sweeping conclusion that opportunity for hearing is a constitutional requisite for fixing all rates

28. Railroad Comm. of Calif. v. Pacific Gas \& Elec. Co., 302 U. S. 388, 392-93 (1938).

29. Morgan v. United States, 298 U. S. 468 (1936) ; Morgan v. United States, 304 U. S. 1 (1937).

30. MIcGrew v. Industrial Comm., 96 Utah 203, 85 P. (2d) 608 (1938).

31. Colteryahn Sanitary Dairy v. Milk Control Comın., 332 Pa. 15, 1 A. (2d) 775 (1938). In both the McGrezw case and the Colteryahn case the statute required a hearing, but the hearings given were held inadequate. In neither case does it appear clearly 'whether the decision was based on constitutional or statutory grounds.

32. Opp Cotton Mills v. Administrator of Wage and Hour Division, 312 U. S. 126 (1941).

33. Id. at 147.

34. Id. at $152-53$.

35. Fuchs, Constitutional Intications of the Opp Cotton Mills Case with Respect to Procedure and Judicial Review in Administrative Rule-Making (1941) 27 WAsu. U. L. Q. 1,7 et seq.

36. The Chicago Junction Case, 264 U. S. 258 (1924), although not a rate case, is closely relevant. The New York Central applied to the ICC for approval of its purchase of two terminal railways which had been previously independent. The application was opposed by six competing carriers. The Commission, after hearing, granted the application, but in a bill for an injunction it was alleged that the finding was wholly unsupported by evidence, and the Court stated: "We must take that fact as admitted for the purposes of this appeal." Id. at 262. It was contended in the Supreme Court that since the power was "purely discretionary" the order need not be supported by evidencc. Mr. Justice Brandeis declared for a unanimous Court: "Congress by using the phrase 'whenever the Commission is of opinion, after hearing, prescribed quasi-judicial action. ... The provision for a hearing implies both the privilege of introducing evidence and 
and prices and wages seems to me quite unjustified. The authority the other way, to be sure, is not very impressive. State courts in Washington ${ }^{37}$ and New Jersey ${ }^{38}$ have held that no hearings of any kind are necessary for fixing minimum wages and milk prices, respectively. The California Supreme Court refused to require a trial technique for fixing milk prices, holding a public meeting sufficient, ${ }^{39}$ and a federal court has likewise found no procedural deficiency in speech-making hearings for fixing milk prices. ${ }^{40}$

We might easily go no further than to observe the three-way split in the authorities - some require trials, some are satisfied with public meetings, and some permit elimination of hearings altogether. Or we might assume that the clear language of the Supreme Court in the gas rate case, since it rests on the Federal Constitution, is controlling of all the cases. But any such conclusion would be oversimplification.

Even though rate-fixing and wage-fixing are all a part of price-fixing in the broad sense, still it is unwise to lump all price-fixing together and fit the same procedure pattern to every proceeding. A public utility rate case has little in common with a price-ceiling problem under the Emergency Price Control Act of 1942 concerning such a question as freezing all retail prices on gasoline in the East, and even less in common with more general freezing orders. Milk prices and wages are different from both utility rates and price ceilings. How to proceed so as to assure exercise of an informed judgment and protection of affected interests does not entail a mere reference to legal conceptualism-putting price-fixing in the slot and getting a jack-pot of trials. The problem is intensely practical. Its solution lies in analyzing the materials needed in the various proceedings, and ascertaining what means will best assure enlightened action that will take into account what the parties have to offer by way of information, persuasion, and testing.

In a familiar type of public utility rate making the principal facts relate to the valuation of the company's property. Probably no one is

the duty of deciding in accordance with it. To refuse to consider evidence introduced or to make an essential finding without supporting evidence is arbitrary action . . ." Id. at $264-65$.

37. Spokane Hotel Co. v. Younger, 113 Wash. 359, 194 Pac. 595 (1920). The court relied on such reasons as: "It would be almost if not utterly impossible to notify every employer of such labor within the state." "Employers have no vested right to employ women or minors, and therefore are not entitled to notice as a matter of right."

38. State ex rel. State Board of Milk Control v. Newarl Mitlk Co., 118 X. I. Eq. 504, 179 Atl. 116 (1935). The court declared of milk price fixing that "such regulation is purely a legislative function," relying heavily on the clearly unsupportable major premise that opportunity for hearing is unnecessary for exercise of a legislative function.

39. Ray v. Parker, 15 Cal. (2d) 275, 101 P. (2d) 665 (1940).

40. Highland Farms Dairy, Inc. v. Agnew, 16 F. Supp. 575 (E. D. Va. 1936), aff d without passing on hearing qucstion, 300 U. S. 608 (1937). 
in better position than the company's representatives to offer affirmative proof and helpful cross-examination and rebuttal. The valuation facts peculiarly concern the property of one company. They are the very stuff of adjudication, the facts to which law and policy and discretion are applied to get the decision. When they are controversial and disputed, they lend themselves to treatment like the adjudicative facts of an ordinary lawsuit, to proof with evidence, to cross-examination and rebuttal, with the grounds of decision limited to the facts in the formal record.

A broad price-ceiling order under the Price Control Act, on the other hand, usually will not depend upon disputed facts which pectliarly concern individual parties, but upon general economic facts, largely susceptible of statistical analysis and presentation. These facts must be found by methods of economist and statistician, not by methods of judge and jury. Informal investigation and research will normally provide initial materials, with possible use of questionnaires, written reports, published materials, interviews and conferences. Disputes over specific facts are unlikely. The realm of controversy will lie in the interpretation of facts, the exercise of discretion, the formulation of policy. Such questions do not call for proof. Although a trial is an unsurpassed device for dealing with conflicting evidence, for determining 'what evidence is to be believed and what evidence is to be disregarded as probably false, and for testing through cross-examination and through rebuttal evidence the veracity, memory, perception, and narration of witnesses, an inquiry into general economic and statistical information seldom requires that process. When a "witness" presents charts and graphs and tables, prepared by subordinates working under him, who in turn derived their information from widespread studies and investigation, what possible sense is there in an oath by which the "witness" swears to tell the truth, the whole truth and nothing but the truth? The oath, cross-examination by adversaries, and other courtroom trimmings usually are not adapted to developing the kind of understanding that must go into a freezing order or a price ceiling.

This is not to say that safeguards to private parties should not be provided, or that parties should not be allowed to participate in providing information and argument and in subjecting materials unfavorable to their interests to their testing processes. Officials may of ten appropriately present the results of investigation and research and invite arguments. Sometimes a hearing resembling that of a legislative committee may be convenient, with constructive cross-examination by presiding officers. But oral presentations may be in many cases less effective than written arguments. The Price Control Act accordingly provides that even when protests are filed the proceedings may be limited to filing affidavits, other written evidence, and briefs, without an oral process. If, however, private interests are numerous, a wide distribution of the 
results of preliminary studies with requests for written comments may not be feasible; indeed, that might not protect those interests as effectively as the machinery which the drafters of the Act showed such rare good judgment in establishing, namely, consultations with industry advisory committees. If the advisory committee is well-chosen and well-informed, and if the officials and members of the committee arrive at mutually satisfactory courses of action, hearings ought not to be constitutionally requisite even though some individual somewhere is dissatisfied with the policies agreed upon. ${ }^{41}$

I do not say that the trial technique is never appropriate in pricefixing proceedings. It is indispensable when specific facts are in dispute. An entire proceeding need not follow the same method throughout; informal investigatory methods coupled with such a device as a representative advisory board may be best suited for finding the economic facts, but a trial will be necessary for finding specific facts where there is conflicting evidence. Or if disputes on specific facts predominate, the balance of convenience may be to use a trial technique throughout. The sole guide should be the practical one of choosing whatever means will be most efficient in providing to the agency the desired understanding while at the same time safeguarding private interests."

Milk prices provide further illustration. The judicial decisions, as we have seen, hopelessly conflict: New Jersey permits milk price-fixing without any hearing, ${ }^{43}$ Pennsylvania holds nothing short of the trial technique is sufficient, ${ }^{44}$ and California is content with public meetings. ${ }^{45}$ The New Jersey court seemed to get its result from the theory of separation of powers; the Pennsylvania court stated an unreasoned conclusion that "interested parties should be accorded opportunity to test the relia-

41. See Feller, Administrative Law Inzestigation Comes of Age (1941) 41 Cor. L. REv. 589, 596: "Let it not be assumed too easily that hearings are a significant protcetion against bureaucratic absolutism. To a slothful administrator a hearing prccedent to regulation may be a God-given onportunity to avoid work and thought. He need only listen with impassively judicial countenance and then forget all he has heard. It is the conference with its give and take of ideas and information, with its possitilities of detailed exploration of minor points and hidden corners which stirs the mind to action. Moreover, there are demonstrably situations where hearings produce little if anything of value."

42. Most of the foregoing discussion of price ceilings is applicable to the bull: ot the wage proceedings before such agencies as the Fair Labor Standards Administration and the Public Contracts Division of the Department of Labor. See Atty Gcn. Comm. Ad. Proc., Division of Public Contracts, Sen. Doc. No. 186, Pt. 1, 76th Cong, 3d Segs. (1940) 30-33; Att'y Gen. Comm. Ad. Proc., Administration of the Fair Lalor Standards Act of 1938, Sen. Doc. No. 10, Pt. 1, 77th Cong., 1st Sess. (1941) 38-40.

43. State ex rel. State Board of Milk Control v. Newark Milk Co., 118 N. J. Eq. 504, 179 Atl. 116 (1935).

44. Colteryahn Sanitary Dairy v. Mrikk Control Comm., 332 Pa. 15, 1 A. (2d) 775 (1938).

45. Ray v. Parker, 15 Cal. (2d) 275, 101 P. (2d) 665 (1940). 
bility of the Commission's evidence before an order is promulgated, revised or changed"; and the California court relied entirely upon its analysis of other cases, to the exclusion of its own creative effort. I submit that one cannot apply a mass of legal doctrine to a vague idea that the function performed is "price-fixing" and come out with a sensible choice of a procedure pattern for performing that function. A finer discrimination is necessary.

Milk price-fixing is not all alike. One must inquire into the kind of materials needed, and their sources, before deciding how to go about getting those materials. Factual disputes may require the process of sworn evidence subject to cross-examination, but these are in fact seldom involved. Milk prices usually are not determined by a proper rate of return on the valuation of a company's property. The facts ordinarily relate not to one company but to thousands, from the farmer with a few cows to the immense dairy farm using mass production methods. Fixing of milk prices by the federal government has for its objective the idea of parity, giving farmers the purchasing power they had during the base period of August, 1919, to July, 1929. Obviously, finding price levels of the base period is a matter for statistical research, not trial. The facts do not peculiarly concern one company and seldom is any party in a position to offer much of value by way of affirmative evidence or cross-examination or rebuttal. The Dairy Section of the Department of Agriculture may well prepare an economic brief and invite comments upon it at a public meeting, as it does, but ordinarily there is no occasion for allowing cross-examination by adversaries.

Furthermore, as the system operates under the Federal Act, parity is not the practical basis for prices. "The actual objective, which has been substantially unchanged since 1934, appears to have been.to establish the highest producer prices in the market that could be sustained for any considerable period of time. In the early stages of the program to have set prices at the prescribed parity levels would have resulted in such a flow of milk as to have flooded the market and expanded its area beyond a territory reasonably to be expected to be a continuous source of supply. These larger supplies would have resulted in subsequent lower prices and a difficult process of supply contraction." 40 In other words, if I understand this correctly, the ultimate basis for determining prices is observation of results; the Department feels its way, increasing the price gradually to accomplish the objectives of the Act, and studies the consequences as it goes along. Such a process surely cannot be conducted by methods of the courtroom.

A more definite standard for milk price-fixing is the so-called historical basis: the average differential between butter prices and the fluid milk

46. Wallace, TNEC Rep., Economic Standards of Government Price Control, Monograph 32 (1941) 84-85. 
price prevailing during the base period is added to current butter prices to arrive at a current hypothetical price for fluid milk. ${ }^{4 \pi}$ If this were the exclusive standard there might be much occasion for argument but none for trial. Another standard is the competitive: to the price of mill: for manufacturing at the edge of the milkshed are added transportation charges to the city, a premuim for quality, a cost of meeting the sanitation requirements, charges for special care in handling, and sometimes a premium for convenience in location. ${ }^{48}$ Each of these factors, of course, could be proved with evidence subject to cross-examination, but I should think that if the Department makes its studies and submits its findings for oral and written comment by parties it is more likely to produce a better official understanding of the facts, a more economical expenditure of taxpayers' money, and more ultimate satisfaction to those affected.

In Indiana, although the milk statute provides that prices shall be "just and reasonable" and that the board shall be guided by (1) cost of production, (2) value of milk in terms of butter, cheese, and evaporated milk, (3) the supply of milk, and (4) the welfare of the general public, the following statement from an annual report of the board indicates the basis in practical administration: "The board consistently follows the plan of consulting local interested parties in each area and giving them what they ask, provided it is reasonable and fair." 49 The price for different areas varied from $\$ 1.85$ to $\$ 2.36$ per hundredweight, and the variations could not be explained on the basis of quality or cost of production. One could hardly say that the board ought to find what the parties want through conducting a trial. Questionnaires, letters, conferences, advisory committees, and, at most, public meetings or open conferences ought to suffice.

In Wisconsin, "custom and bargaining power" were once the basis for milk prices, and "competition" is now the basis." To find what price a marketing cooperative has agreed upon with distributors hardly calls for a trial. The chief component of "competition" is the price of products manufactured from milk from outside the area; finding that price does not require courtroom methods.

In California, where wholesale and retail prices, as well as producer prices, are fixed, the director must find "that such prices are not more than reasonably sufficient to cover all necessary costs, including a reasonable return upon necessary capital invested, of reasonably efficient distributors and retail stores." In one area of 49 distributors the director

47. Id. at $\mathrm{S5}$.

48. Ibid.

49. Id. at 151 , quoting Board Report of April, 1938.

50. Id. at 168. Another factor that has been used in Wisconsin is cost of production, which, if thoroughly developed, is more likely to call for trial methods. 
had cost studies made of four, and based the proposed prices on the plant with lowest cost of the four, after eliminating unnecessary expenses. ${ }^{51}$ Disputes of fact concerning one of these distributors certainly would make trial appropriate, but it seems likely that controversy will normally concern not so much the underlying facts as the application of principles of cost accounting.

Despite rather sweeping pronouncements from the Supreme Court, due process probably does not require oral presentation of evidence even in all public utility rate cases. ${ }^{52}$ The category of rate cases is too broad for uniform application of the same procedure pattern. ${ }^{63}$ In its latest annual report the ICC states: "Approximately 41 per cent of the total number of formal complaints were handled by the shortened procedure method as compared with 30,35 , and 34 per cent during the three preceding years." ${ }^{54}$ Under the shortened procedure the parties exchange

51. Id. at 133 .

52. The Morgan cases did involve fixing rates for as many as fifty marketing agencies, and the Court required a trial as a matter of "fair play". Morgan v. United States, 298 U. S. 468 (1936), 304 U. S. 1 (1937). But I do not interpret these cases as authority against my major thesis. The decisive consideration is that the inquiry in these cases was not into the general facts concerning all fifty agencies. The rates had to be fixed for each marketing agency, and inquiry had to be made concerning the volume of business of each, the number of necessary employees of each, the cost of operating each business, and the necessary investment in each business. The factual inquiries werc narrow and specific, each party being the primary source of information concerning his business. Trial methods were therefore appropriate. Of course, emphasis upon written materials, with a minimization of the oral process, might have been a desirable way of developing facts about some of the marketing agencies. See the lower court's opinion in the first Morgan case for a detailed statement of facts. \& F. Supp. 766 (W. D. Mo. 1934).

53. In the Preliminary Report to the Council and Section of the American Bar Association by the Committee on the Improvement of Procedure in the Trial of Rate Litigation before State Commissions and the Courts, submitted at the Association's annual meeting, held in Atlantic City on September 15 and 16, 1931, the following appears: "The view is widely held that proposals for changes in rates may in at least a large percentage of instances be considered by Commissions by much the same approach and in much the same manner as is followed by fair-minded utility exccutives. This would involve primarily an examination of the revenue produced by existing rates, changes in demand for service and in operating expenses, availability of new capital, etc., and a weighing of such factors with a view to reaching a decision fair to all parties. This, of course, would mean in those instances an initial procedure far different from that which would result if formal determination of fair value were actually to be the starting point in rate fixing. And if business fairness to both parties is to furnish a primary standard in seeking agreement upon acceptable rates, it seems clear that informal conferences and negotiation furnish a more suitable procedure than formal hearings with examination and cross examination of witnesses. The development of specific measures for the encouragement of such informal methods of conciliation is thought by some to be a promising line of advance in the improvement of procedure in rate cases." Such provocative thought as this can hardly be foreclosed by sweeping generalizations about duc process of law.

54. ICC Ann. Rep. (1941) 77. 
sworn memoranda of fact and written arguments, and the examiner prepares a proposed report without the benefit of oral presentation of evidence. In only about one case in twenty do contradictions of fact appear in the memoranda, and even then the disputes are usually easily resolved.

"Controversies in rate cases usually do not concern questions of truth and falsity, or questions of primary or evidentiary facts. There is little about which a witness could readily perjure himself. Most of the facts have already been committed to writing in both the shipper's records and in the carrier's records, such as the date of shipment, the charges collected, the weight, the route over which the shipment moved. The affiants are usually members of the traffic departments of the carriers who prepare the shipments, and the officers or employees of the shipping company who have handled the transportation. Of course, dispensing with hearings means dispensing with cross-examination, and dispensing with crossexamination is shocking to some lawyers. But when primary facts are not in dispute, there is no very convincing reason why the evidence on each side should not be presented in writing rather than orally. . . . Some members of the Commission's staff are firmly of the opinion that the shortened procedure sometimes results in better decisions than hearing procedures, by reason of the greater precision that is possible when facts are stated in writing rather than orally." 35

Although the shortened procedure in the ICC now rests entirely on consent of parties, the Department of Agriculture has discretion to require it in certain cases, and much can be said in favor of allowing the ICC the same discretion. ${ }^{58}$

Due process certainly must not prematurely foreclose experimentation with substitution of written for oral methods. A so-called "modified" procedure in the ICC seems promising. ${ }^{57}$ The full potentialities of written methods remain to be explored, and judicial language uttered without such devices in mind cannot properly be regarded as an obstacle to sound trial-and-error development. ${ }^{\text {"s }}$

55. Att'y Gen. Comm. Ad. Proc, Interstate Commerce Commission, SE:. Doc. No. 10, Pt. 11, 77th Cong., 1st Sess. (1941) 24-25.

56. Compare Report (1941) 69.

57. For a summary of what has heretofore been called the modified procedure, sse ICC ANN. REP. (1924) 7. As of MIay, 1942, the ICC has under consideration a tentative draft of rules which prescribe a new modified procedure. The Commission declares: " $A$ s proposed in the instant submission modified procedure . . . would not be defundent ufun consent, and oral hearing would be confined to matters upon which there is dicagresment." ICC Proposed Revision of the Rules of Practice (1942) 34. See Brown, Ptsllis: Service Commission Procedure-A Problem and a Suggestion (1938) 87 U. of P.. L. REV. 139.

58. The Attorney General's Committee recommended that "the practice of holding public hearings . . . should be continued and established as standard administrative prac- 
Separation-of-Powers Classifications as Criteria. An uncritical reading of judicial opinions on the requirement of opportunity to be heard would lead inexorably to the conclusion that the trial technique is required for "judicial" action but not necessarily for "legislative" action. ${ }^{\text {bD }}$ Yet a critical examination of these opinions leads to just as inexorable a conclusion that the attachment of separation-of-powers labels to functions is an evasion rather than a solution of the problem.

Recognition of the difficulty or impossibility of distinguishing legislative from judicial functions is at last becoming commonplace. The classical statement of Holmes is increasingly rejected: "A judicial inquiry investigates, declares, and enforces liabilities as they stand on present or past facts and under laws supposed already to exist. . . . Legislation on the other hand looks to the future and changes existing conditions by making a new rule to be applied thereafter to all or some part of those subject to its power." 60 It has been observed that "almost all governmental orders have the characteristic of prescribing or forbidding future conduct. A judgment for money damages, an order for the abatement of a nuisance, and a decree compelling an employer to bargain collectively with a union must be executed in the future. . . ."01 And courts in creating law frequently look to the future and make new rules. Perhaps the most successful attempt to classify is that of Professor Fuchs, who rejects the categories of legislative and judicial, and marks out a separate category known as rule-making. He offers a useful and a workable definition: "The most obvious definition of rule-making and the one most often employed in the literature of administrative law asserts simply that it is the function of laying down general regulations as

tice" for several categories of cases, including "the fixing of prices and wages." Sec REPORT (1941) 107-08. This flat recommendation might well have been qualified. The Committee approves the shortened procedure as used in the Department of Agriculturc. Id. at 69 . And I am confident that it would approve the provisions of the Emergency Price Control Act of 1942, setting up industry advisory committees, providing that hearings may be eliminated, and providing for limiting proceedings to affidavits, other written evidence, and briefs.

59. The Harvard Law Review surprisingly relied on separation-of-powers labels in solving with the greatest of ease the question of requirement of hearings under the Price Control Act: "While the formal hearing is essential to quasi-administrative actionthe issuance of orders or findings or the taking of action applying to named or specified persons or situations'-it can be dispensed with in quasi-legislative action-'the issuance of regulations or the making of determinations which are addressed to indicated but unnamed and unspecified persons or situations.' Consequently, since the contemplated price regulations will be directed to classes and not individuals, their quasi-legislative nature would seem to allow the EPCA validly to dispense with formal notice and hearing to the effected parties." Comment, American Economic Mobilisation (1942) 55 Hatv. L. REv. 427, 490-91.

60. Prentis y. Atlantic Coast Line Co., 211 U. S. 210, 226 (1908).

61. Fuchs, Procedure in Administrative Rule-Making (1938) 52 Harv. L. REv. $259,260$. 
distinguished from orders that apply to named persons or to specific situations." 62 This seems clearly preferable to the separation-of-powers classification customarily made by the courts, even though Mr. Fuchs himself suggests that it has its difficulties. Of course, some governmental action is usually regarded as legislative even though it is not rule-maling and even though it culminates in orders that apply to named persons or to specific situations. Thus, a proceeding before the Tariff Commission concerning the fixing of the duty on nitrates is regarded as legislative even though there is only one party on one side and two parties on the other. ${ }^{63}$ The notion persists that rate-making for a single company is legislative. It is easy to say that to order a railrond to use power reverse gears or to eliminate a grade crossing or to abandon a track or to extend a line is legislative rather than judicial, simply because such an order has little in common with the kind of business that is handled by courts. Indeed, I am inclined to think that if one must classify administrative action along the lines of the legislative and the judicial by using some one criterion, the most satisfactory test may be the appeal to tradition: action resembling what courts traditionally do is judicial and action resembling what legislatures customarily do is legislative. Thus, a court does not fix duties on imports; legislatures do; therefore the function when performed by a commission is legislative. Such a form of reasoning is often more helpful than any of the other tests. But, using any test, what is the inspection of a locomotive to ascertain whether or not it should be withdrawn from service, or a proceeding with one named carrier on one side and innumerable unnamed shippers on the other to determine whether or not an exception to the long-and-short-haul clause should be permitted, or an investigation of an airplane crash to get information to prevent recurrence of similar accidents, or approval of giving less than thirty days' notice on changing rates, or a general investigation of freight forwarding practices to determine whether some action ought to be taken and if so what?

The label logic of separation-of-powers classification is too often specious. Why should a particular function of some agency be legislative or judicial? Why not recognize that the categories are largely survivals of governmental processes having little in common with the

62. Id. at 263 .

63. Norwegian Nitrogen Products Co. v. United States, 28S U. S. 294 (1933). Mr. Justice Cardozo reasoned that hearings before congressional committees vere not trials, that the function was transferred from the committees to the Tariff Commission and the President, and that "The inference is, therefore, a strong one that the kind of hearing assured by the statute to those affected by the change is a hearing of the same order as had been given by congressional committees when the legislative process was in the hands of Congress and no one else." Id. at 305 . I doubt the validity of such reasoning, although I agree with the result. See infra p. 1115, on differences between legislatures and agencies with respect to requiring hearings. 
administrative process, and that a modern function may be somewhat judicial and somewhat legislative but neither wholly one nor wholly the other?

Furthermore, if we must attach these labels to agencies' functions (and deeply rooted habits do not suddenly disappear), surely there is good sense in getting rid of the false and misleading notion that for the sake of some pretty symmetry a function must be classified the same way for all purposes. I think that a statute conferring a rate-fixing power upon a court might well be held unconstitutional on the ground that the power is legislative, and that at the same time the same judges might consistently hold that a trial technique must be used by a commission in fixing rates because rate-fixing is judicial. And so of other powers. In order to classify wisely, we must know the purpose of the classification, and a classification appropriate for one purpose may be inappropriate for another.

Thus, if the purpose of classifying some function is to determine whether or not the trial technique should be required, the court should select the appropriate label in accordance with its views on the question whether or not the function is one that calls for that technique. The professed idea about cause and effect must be reversed: instead of saying that a function is judicial and that therefore a trial is requisite, we shottld say that since a trial is desirable we may call the function judicial for this purpose; or since a trial is unnecessary the action may be dubbed legislative. I believe that more often than not this is the sequence of thought in the minds of alert judges. A good example is the first Morgan case," involving the fixing of rates for stockyard services. Chief Justice Hughes could have gone to the precedents and found that the function was legislative: in Prentis, Holmes had said that "the establishment of a rate is the making of a rule for the future, and therefore is an act legislative, not judicial"; is in Ben Avon, McReynolds had proclaimed that "the order here involved . . . was legislative";" and the Chief Justice himself had declared flatly in St. Joseph only one month before the first Morgan case that "The fixing of rates is a legislative act." ${ }^{07}$ But the Chief Justice, wisely, did not go to the precedents and find the label. He looked to the purpose of the classification: "A proceeding of this sort requiring the taking and weighing of evidence, determinations of fact based upon the consideration of the evidence, and the making of an order supported by such findings, has a quality resembling that of a judicial proceeding. Hence it is frequently described as a proceeding of a quasi-judicial character." ${ }^{\circ}$ The Chief Justice did not decide on

64. Morgan v. United States, 298 U. S. 468 (1936).

65. Prentis v. Atlantic Coast Line Co., 211 U. S. 210, 226 (1908).

66. Ohio Valley Water Co. v. Ben Avon Borough, 253 U. S. 287. 289 (1920).

67. St. Joseph Stock Yards Co. v. United States, 298 U. S. 38, j0 (1936).

68. 298 U. S. at 480. 
the basis of the label what the procedure should be. The Chief Justice decided on the basis of the procedure what the label should be. Other courts would do well to follow this method of reasoning. ${ }^{69}$

Of course, if we use this approach in trying to discover when the trial technique should be required, we get no help from separation-ofpowers concepts, winding up exactly where we started. That is as it should be. After we find on other bases whether or not the trial technique should be required, we may then, but only then, say that the label of a function for this purpose is judicial or legislative or what-not.

The Analogy to Legislative Enactments Without Hearings. Clearly it does not follow that because a legislature may take certain action without providing opportunity for hearing or other participation by parties an agency may do likewise. ${ }^{70}$ A legislature is a representative body whose members are supposed to and to a large extent do reflect the will of their constituents. Those affected by a pending measure are not denied opportunity for participation in the determination, for they are presumably represented within the legislature itself. This element of representation is usually lacking in the administrative process. When private parties tend to obstruct an agency in gaining its objectives, those parties seldom have spokesmen among the membership of the agency. If their arguments and evidence are to enter into the formulation of the governmental action, special procedural devices must be made available - something in addition to what a legislature provides. That the legislature is permitted to act without giving opportunity for hearing is only another illustration of the thoroughly sound proposition that devices other than hearings are often superior to hearings as protection against arbitrary action.

Like a legislature, a municipal government, by reason of its representative character, may sometimes act without providing opportunity to be heard even though an administrative body might be required for the same action to provide such opportunity. Thus, the Supreme Court has permitted a municipality to require a railroad to eliminate a grade crossing without opportunity for hearing ${ }^{71}$ but has set aside for lack of hear-

69. See the similar reasoning of REPORT (1941) 106-07: "Rate fising for public utilities has been attended by a high degree of procedural formality . . . In these instances, however, the number of enterprises having their rates fised in 3 single proceeding is quite limited, with the consequence that rate fixing has come to be thought of as adjudication rather than as rule making."

70. This idea that an agency may use any methods a legislature may use runs through a good many cases. See, e.g., Heaith Dep't v. Rector, 145 N. Y. 32, 40-41, 39 N. E. 833 , 835-36 (1895) ; Spokane Hotel Co. v. Younger, 113 Wash. 359, 365, 194 Pac. 595, 593 (1920). For express rejections of the idea, see Southern Ry. v. Virginia, 290 U. S. 190, 197 (1933); REPORT (1941) 101.

71. Chicago, B. \& Q. R. R. v. Nebraska, 170 U. S. 57,77 (1898). 
ing a commission order of the same kind. ${ }^{72}$ So, in improvement and assessment cases a legislature or a municipality may determine benefit to a locality without allowing opportunity for hearing, ${ }^{73}$ but the Supreme Court requires an administratiye body to provide such opportunity. ${ }^{74}$ In cases involving special benefit to particular property owners, the Supreme Court permits a legislature to make the determination without opportunity for hearing, ${ }^{75}$ but not a municipality or county government. ${ }^{70}$

In a few agencies members represent constituencies as in a legislature. Thus, the thirty-six members of the National Railroad Adjustment Board are not government employees but draw their pay from the railroads and railway labor unions. ${ }^{77}$ Even though disputes are hotly contested, trial is never used. Indeed, in more than half the cases (virtually all crucial ones) the members of the board deadlock and the decision is made by a referee to whom the parties may never present evidence and usually may present neither written briefs nor oral arguments. But in a substantial sense, on account of the board's representative character, the parties do have opportunity to influence decisions, for board members exert every effort to persuade the referee. Were it not for this, denial of opportunity to be heard before the referee would be unfair, unless other adequate means of participation were provided.

The National Defense Mediation Board was made up of four enl. ployer representatives, four employee representatives, and three public representatives, with alternates in proportionate numbers. ${ }^{78}$ Although more than two-thirds of the cases were settled by mediation without formal recommendation by a panel of the board, recommendations were made in many important cases, and sanctions were applied in such a way that recommendations were sometimes the equivalent of adjudications. The Board, with some exceptions, did not employ trial methods. The representative character of the Board, the informal hearings in which mixtures of facts and argument were freely presented, and the predominant purpose to effect settlements through negotiation and bargaining combined to provide a system far superior to an orthodox trial before non-partisan officers. And probably most parties found the safeguards under the Board's system preferable to those provided by trial.

72. Southern Ry. v. Virginia, 290 U. S. 190 (1933).

73. E.g., Chesebro v. Los Angeles County Flood Control Dist., 306 U. S. 459 (1939).

74. E.g., Browning v. Hooper, 269 U. S. 396 (1926).

75. E.g., Wagner v. Baltimore, 239 U. S. 207 (1915).

76. Paulsen v. Portland, 149 U. S. 30 (1893); but cf. Withnell v. Ruecking Constr. Co., 249 U. S. 63 (1919). See the collection of cases and excellent analysis in GreLrons, Administrative Law-Cases and Comments (1940) 360-64.

77. Att'y Gen. Comm. Ad. Proc., The National Railroad Adjustmem Board, Sws. Doc. No. 10, Pt. 4, 77th Cong., 1st Sess. (1941).

78. Jaffe and Rice, Report on the Work of the National Defense Mcdiation Board (1942) (mimeographed). 
The Number of Parties as a Criterion. Some refusals of opportunity to be heard rely heavily on the idea that hearings are not feasible when a large number of parties may be affected. These cases stem from Bi-Metallic Co. v. Colorado, ${ }^{79}$ which permitted a blanket increase in valuation of all Denver property without opportunity for taxpayers to be heard. Mr. Justice Holmes declared for a unanimous Court: "Where a rule of conduct applies to more than a few people it is impracticable that every one should have a direct voice in its adoption. . . . There must be a limit to individual argument in such matters if government is to go on." ${ }^{80}$ The Court distinguished Londoner i'. Dene'er, ${ }^{81}$ which required opportunity to be heard where a local board determined "whether, in what amount, and upon whom" a tax for paving a street should be levied for special benefits, on the ground that, "A relatively small number of persons was concerned, who were exceptionally affected, in each case upon individual grounds." 82 Other courts, following this lead, have emphasized the number of parties or have made it the sole criterion. ${ }^{83}$

Requiring the trial technique in the Londoner case and refusing to require it in the Bi-Metallic case was thoroughly sound. But the cases should not be interpreted as supporting the proposition that the requirement of a hearing should depend upon the number of parties. The emphasis should be upon the "individual grounds". The true test is whether the facts are general or concern individuals. ${ }^{84}$ If facts concerning the extent to which $X$ will specially benefit from the improvement are disputed, those facts peculiarly concern $X$, and the dispute should not be resolved without giving $X$ a chance to offer his proof, to know the opposing proof and argument, and to rebut and cross-examine. But if the dispute is whether all property valuation should be horizontally raised, the needed facts do not peculiarly concern any individual and the trial technique will normally be inappropriate. No matter how numerous the parties, a trial usually is the expedient device for resolving factual controversies that relate to an individual, and no matter how few the parties, a trial is usually unnecessary for developing general facts. The criterion for using the trial technique thus is not the number of parties. There is, however, a high correlation between numerous parties and the generality of the facts, and between few parties and the specificity of the facts;

79. 239 U. S. 441 (1915). Contra: Draffen v. Paducah, 215 Ky. 139, 234 S. W. 1027 (1926) ; Northwestern Bell Tel. Co. v. Board, 119 NYeb. 138, 227 N. W. 452 (1929).

S0. 239 U. S. at 445.

81. 210 U. S. 373 (1908).

S2. 239 U. S. at 446.

83. Hammond v. Winder, 100 Ohio St. 433, 126 N. E. 409 (1919); Common Council of City of Watertown v. Dep't of Finance, 59 S. D. 573, 241 N. W. 731 (1932); Baker v. Paxton, 29 Wyo. 500, 540, 215 Pac. 257, 270 (1923).

84. See discussion of fixing rates, prices, and wages, supra f. 1103 et seq. 
accordingly courts which make the number of parties the criterion usually reach a good result.

Another aspect of the interpretation often given the Bi-Metallic case is questionable. A courtroom type of proceeding to determine whether all property valuation in Denver should be increased would be clumsy, expensive, and inefficient, and the Court properly denied the opportunity. But the taxpayers should not be denied all opportunity to reach the eyes and ears of the board. The board might announce what action it contemplates, with a statement of supporting reasons, and invite written comments; or it might permit limited arguments to be made at a public meeting hearing. To assure informed action and to give taxpayers the satisfaction which comes from a chance to influence decision, opportunity for some such participation is desirable, even though constitutional principles may not require it. The reasons behind the democratic principle are applicable.

The notion that hearing cannot or should not be attempted when parties are numerous is false. Agencies have held hearings in as many as twenty-five cities on a single question. The ICC has had four or five hearings on the same question progressing simultaneously in a Chicago hotel. I find no trace of breakdown of any hearing on account of too many parties. What happens in practice is that the more numerous the parties the more general the inquiry and the less each individual has to contribute and hence the fewer the individuals who attend. Indeed, when large groups lack organization making possible effective participation through representatives, the agency's problem is often the reverse of overcrowding the hearing room. The agency discovers that calling a hearing for few or none is less effective than submitting questionnaires, or proposing tentative regulations and inviting written comments, or consulting with representative advisory committees. And sometimes participation must be made even easier; when the ICC wanted to understand the problems and points of view of little motor carriers who keep books in their hip pockets, the Commission sent out a representative to interview thousands of such individuals. ${ }^{85}$

Privileges and Property Rights. The cases are legion which assert that privileges may be taken away without opportunity for hearing but that property rights are protected by due process and may not be adversely affected without opportunity to be heard. Typical is the following: "The operation of a motor vehicle on the public highways is not a natural right, nor is license to do so a contract, or property right, in a constitutional sense. It is merely a conditional privilege which may

85. Att'y Gen. Comm. Ad. Proc., Interstate Commerce Commission, SEs. Doc. No. 10, Pt. 11, 77th Cong., 1st Sess. (1941) 85-86. 
be suspended or revoked . . . even without a notice or an opportunity to be heard." cation of licenses for automobile drivers, ${ }^{87}$ dance halls, ${ }^{83}$ pool rooms, ${ }^{83}$ liquor dealers, ${ }^{90}$ milk dealers, ${ }^{91}$ lobster fishers, ${ }^{92}$ theaters. ${ }^{93}$ But when more dignified callings are involved, this is apt to be typical: "YVhether the right to practice law or medicine is property, in the technical sense, it is a valuable franchise, and one of which a person ought not to be deprived, without being offered an opportunity, by timely notice, to defend it." 94

So striking is the difference in language in the two types of cases that one commentator has thus summarized the law:

"If a given occupation be calculated to serve some useful purpose advantageous to the general public or any considerable number thereof, and if the pursuit of such occupation affords but slight, if any, opportunity for the infiction of general and substantial injury to the public health, safety, morals or convenience, then a license to engage in such occupation confers upon its holder a right which cannot be divested without notice to him and opportunity for him to be heard; but if an occupation be one which serves no socially useful purpose or which affords opportunity to jeopardize or injure the health, safety, morals, or convenience of large numbers of people, then a license to engage therein is, at most, a mere privilege, and is subject, due cause being shown, to summary revocation in the public interest." 95

Certainly one may readily agree that whenever a disputed question of specific fact is involved a doctor, lawyer or other professional man should not be deprived of his right to practice without opportunity for

86. Nulter v. State Road Comm., 119 W. Va. 312, 317-18, 193 S. E. 349,552 (1937).

87. Commonwealth v. Cronin, $336 \mathrm{~Pa}$. 469, 473, 9 A. (2d) 408,410 (1939); La Plante v. State Board of Pub. Roads, 47 R. I. 258, 261, 131 Att. 641, G43 (1926); Law v. Commonwealth, 171 Va. 449, 454, 199 S. E. 516, 519 (1938).

88. People ex rel. Ritter v. Wallace, 160 App. Dir. 787, 789, 145 X. Y. Supp. 1041, 1042 (2d Dep't 1914).

89. Commonwealth v. Kinsley, 133 Mass. 578, 579 (18\$2).

90. State Board of Equalization v. Superior Court, 42 P. (2d) 1076,1077 (Cal. App. 1935) ; Dorley Apt. Co. v. Springer, 22 A. (2d) 397, 401 (Del. Sup. Ct. 1941); Flocel: v. Bureau of Revenue, 100 P. (2d) 225 (N. MI. 1940).

91. People ex rel. Lodes v. Dep't of Health, 159 N. Y. 187, 191-92, 82 N. E. 187 (1907).

92. State v. Cote, $122 \mathrm{Mie} 450,451,120$ Atl. 538, 538-39 (1923).

93. Thayer Amusement Corp. v. Moulton, 7 A. (2d) 6S2, 686-\$9 (R. I. 1939); MreKenzie v. MícClellan, 62 Misc. 342, 344, 116 N. Y. Supp. 645, 646 (Sup. Ct. 1909).

94. People v. 11 CCoy, 125 Ill. 289, 297, 17 N. E. $786,78 S$ (188S). See collection of cases and analysis in GELLHORN, op. cit. supra note 76, at 372-82.

95. Tuttrup, Necessity of Notice and Hearing in the Recocalion of Occupational Licenses (1927) 4 WIs. L. Rev. 180, 186. 
hearing. ${ }^{06}$ But can one justify taking away the right to pursue other lawful callings without affording opportunity to be heard upon such disputed fact questions? I think not. If the holder of an occupational license is charged with unlawful conduct which he denies, the fact question is precisely the kind that lends itself to determination through the traditional process of testimony of witnesses subject to cross-cxamination, and unless some special reason exists for dispensing with the trial technique the question ought to be determined by that method. The idea of privilege does not constitute such a special reason but is an artificial abstraction founded upon an unsound conceptualism. Operating a motion picture theater or pop-corn stand or billiard parlor is no more a mere privilege than practicing law or medicine; all are lawful callings which involve varying investments and which are important to the individuals who pursue them. If taking away the license of the doctor or lawyer without opportunity for hearing is unjust, revoking a driver's license or that of a dance hall operator without opportunity for hearing is likewise unjust. True, the state may prohibit callings regarded with disfavor, but to reason from that proposition to the conclusion that administrative officers may take away important interests without opportunity to be heard on disputed fact questions is a nonsequitur. To prohibit some occupation altogether involves no unfairness; to allow an administrative officer to destroy a profitable business on the ground of an alleged unlawfulness which is disputed, without allowing the owner a chance to know the charges and to meet them with evidence and argument, involves unfairness apparent to any eyes not blinded by dazzling conceptualism. To find that alert judges woulcl permit such injustice would be amazing.

Indeed, a careful reading of the cases reveals that the holdings, as distinguished from the language, seldom produce such injustice. The commentator above quoted relies upon fourteen cases reciting that privileges may be withdrawn without opportunity for hearing. Five permitted revocation of licenses on the basis of previous convictions in court ${ }^{97}$ this result is entirely appropriate, unless it affirmatively appears, as it did not in any of these cases, that the fact of previous conviction is disputed. In two others a hearing had been held. ${ }^{88}$ In three there was either opportunity for de novo judicial review or the court itself

96. Goldsmith v. United States Board of Tax Appeals, 270 U. S. 117 (1926) held opportunity for hearing constitutionally requisite for barring attorney from practice before the Board.

97. State $e x$ rel. Nowotny v. Milwaukee, 140 Wis. 38,121 N. W. 658 (1909); Martin v. State, 23 Neb. 371,36 N. W. 554 (1888) ; Cassidy v. City of Macon, 133 Ga, 689, 66 S. E. 941 (1909) ; Sprayberry v. Atlanta, 87 Ga. 120, 13 S. E. 197 (1891); Pcople v. Myers, 95 N. Y. 223 (1884).

98. Klafter v. Examiners, 259 Ill. 15, 102 N. E. 193 (1913); State $e x$ rel. Chapman v. Board, 34 Minn. 387 (1885). 
in passing upon the hearing question found the disputed facts. ${ }^{83}$ In one case, not an individual license but the revocation of licenses of all "jitney" buses in a city was involved, and the action was preceded by public meetings; ${ }^{100}$ when the facts are general and do not peculiarly concern individual parties, and when the primary question is one not of fact but of policy, a trial is ill-adapted to the problem and should not be used unless specific facts are disputed which may as a practical matter best be resolved by the process of testimony under oath and subject to cross-examination. This case is therefore sound in its holding, despite the court's language about privilege.

The remaining three of the fourteen cases rest in holding upon privilege. The Nevada court relied upon privilege and the protection afforded by requiring a unanimous vote of the city council in revoling a liquor license. ${ }^{101}$ The Massachusetts court reasoned: "A licensee takes his license subject to such conditions as the Legislature sees fit to impose, and one of the statutory conditions of this license was that it might be revoked by the selectmen at their pleasure." 102 The Rhode Island court likewise was persuaded by the notion that a license could reserve the power of revocation without opportunity for hearing. ${ }^{103}$ This approach does have its appeal, especially since the only question is one of due process; the state need not grant any liquor or poolroom licenses, and, therefore, it may constitutionally grant licenses with the understanding that they may be summarily revoked. Nevertheless, I think it is unwise to allow administrative officers to destroy business interests without an opportunity for hearing when facts concerning the licensee's past conduct are disputed. ${ }^{104}$

The privilege cases discussed are old, and it has been suggested that "recent cases may indicate a changed attitude toward such licenses." 103 Unfortunately, however, the privilege concept is deeply imbedded in judicial expression and is still decisive of some cases. Thus, since 1935 many licenses have been branded privileges revocable without opportunity

99. People $e x$ rel. Lodes v. Dep't of Health, 189 N. Y. 187. 82 N. E. 187 (1907); People ex rel. Ritter v. Wallace, 160 App. Div. 787, 145 N. Y. Supp. 1041 (2d Dep't 1914).

100. Burgess v. City of Brockton, 235 Mass. 95, 126 N. E. 456 (1920).

101. Wallace v. Mayor of Reno, 27 Nev. 71, 73 Pac. 523 (1903).

102. Commonwealth v. Kinsley, 133 Mass. 578,579 (1882).

103. Child v. Bemus, 17 R. I. 230, 21 Atl. 539 (1891).

104. Of course, our primary quarrel might well be with the statutes and ordinances which establish such a scheme rather than with the courts which allow it under due process clauses. But in this observation lies a significant point: when courts having power to give content to due process clauses refuse to disapprove administrative methods, even when the ground is some such conceptualism as that surrounding the privilege idea, legislators and administrators easily get the erroneous impression that the courts are approving those methods, with the result that a deficient system remains unimproved.

105. Comment (1934) 34 CoL. L. REv. 332, 339 n. 47. 
to be heard - drivers' licenses in Pennsylvania, Virginia and West Virginia, ${ }^{106}$ a license to show motion pictures in Rhode Island, ${ }^{107}$ liquor licenses in California, New Mexico, and Delaware. ${ }^{108}$ Although most of the results can be justified on other grounds, the danger that the doctrine of privilege will produce injustice is illustrated by a 1941 Delaware decision. ${ }^{109}$ The Liquor Commission "suspended for a stated period" a hotel's license to sell liquor, on the ground of alleged violation of a regulation against drinking after a certain hour. In upholding the Commission's action despite lack of opportunity for hearing the court reasoned that the license "is not property" but "a mere temporary permit . . . to do that which otherwise would be unlawful." Whether or not there was a substantial dispute of fact - the crucial consideration - does not appear. For all that does appear, the Commission may have been acting upon indirect information which the hotel, if given the opportunity, could readily have disproved. And if the facts were disputed, the question is precisely the kind for which trial methods are designed. To give the hotel opportunity to know the evidence against it and the opportunity, however informal, to meet that evidence, would have caused little delay, slight expense, no substantial prejudice to the public interest, and at the same time would have protected against the kind of arbitrary official action that promotes distrust of government.

In other contexts the same concept of privilege recurs. Thus Congress can exclude all aliens, ${ }^{110}$ or cease to provide the second-class mailing privilege at less than the cost of the service, ${ }^{111}$ or deny compensation to veterans, ${ }^{112}$ or discontinue workmen's compensation benefits for federal employees, or curtail the importation of goods from abroad. ${ }^{113}$ The states may deny unemployment compensation or old-age assistance or direct relief or other benefits in the nature of bounties. ${ }^{114}$ True, such.

106. Commonwealth v. Cronin, $336 \mathrm{~Pa}$. 469, 9 A. (2d) 408 (1939) ; Law v. Commonwealth, 171 Va. 449,199 S. E. 516 (938); Nulter v. State Road Comm., 119 W. Va. 312, 193 S. E. 549 (1937).

107. Thayer Amusement Corp. v. Moulton, 7 A. (2d) 682 (R. I. 1939).

108. State Board of Equalization v. Superior Court, 5 Cal. (2d) 374,42 P. (2d) 1076 (1935) ; Darling Apt. Co. v. Springer, 22 A. (2d) 397 (Del. Sup. Ct. 1941) ; Flocck v. Bureau of Revenue, 100 P. (2d) 225 (N. M. 1940).

109. Darling Apt. Co. v. Springer, 22 A. (2d) 397 (Del. Sup. Ct. 1941).

110. Ekiu v. United States, 142 U. S. 651 (1892), upheld exclusion of an alien without opportunity for hearing, even though the exclusion was based upon facts concerning the individual which were disputed. The Court relied upon absence of statutory requircment of hearing and the idea of sovereign power to forbid entrance of foreigners. $C$. Chin Yow v. United States, 208 U. S. 8 (1908) granting writ of habeas corpus because of lack of opportunity to be heard.

111. Compare Public Clearing House v. Coyne, 194 U. S. 497, 507 (1904).

112. Compare Lynch v. United States, 292 U. S. 571, 587 (1934).

113. Compare Auffmordt v. Hedden, 137 U. S. 310 (1890); Oceanic Steam Nav. Co. v. Stranahan, 214 U. S. 320,335 (1909).

114. I do not advocate formal hearings in the administration of old age assistance, direct relief, WPA jobs, and the like. But the reason is not that the recipients are get- 
benefits often may be denied altogether, without opportunity for hearing, when the governmental action rests upon general facts and policy. But when the decision involves disputed facts concerning an individual - his qualifications or circumstances or past conduct - that individual normally should be given a chance to know the evidence adverse to his interest and to meet it with evidence and argument. A procedure which is unfair for inflicting a penalty is not rendered fair by using it for withdrawing a benefit. If the government or a state chooses to provide benefits, even outright gifts, the method of determining the individual recipients must still be fair.

Furthermore, what would be gratuities if given by any other donor are not entirely gratuities when provided by the Government, for they are paid for by taxation in which donees in varying degrees share. The language of Mr. Justice Brandeis is broadly applicable to all these questions: "The contention that, because the rates are non-compensatory, use of the second-class mail is not a right but a privilege which may be granted or withheld at the pleasure of Congress, rests upon an entire misconception, when applied to individual members of a class. The fact that it is largely gratuitous makes clearer its position as a right; for it is paid for by taxation." 110

The Government, surprisingly, awards workmen's compensation benefits to its own employees through a system which does not provide for hearings in finding controverted facts; even informal conferences are rare. ${ }^{116}$ I suppose the privilege idea might be invoked to justify the

ting privileges; the reason is that the problems are better handled by informal investigotions. Nevertheless, where facts are disputed a claimant should be allowed to lnow the findings in support of an adverse decision and given a chance to show informally that the findings are in error. Even if the Government is regarded as a donor (which many question), still it is a Government, and a Government should follow fair methods.

115. Brandeis, J., dissenting, Milwaukee Pub. Co. v. Burleson, 255 U. S. 407, 417, 433 (1921). But cf. Brandeis, J., concurring in St. Joseph Stoclyards Co. v. United States, 29 U U. S. 38, 73, 77 (1936): "When dealing with constitutional rights (as distinguished from privileges accorded by the Government, United States v. Babcods, 250 U. S. 328,331 ) there must be the opportunity of presenting in an appropriate proceeding, at some time, to some court, every question of law raised . . ."

Government counsel had the audacity to argue very recently that "no individual has a natural or constitutional right to have his communications delivered by the postal establishment of the government, and hence that a fraud order may be issued summarily and without any notice or any hearing." Happily, the court rejected the contention, declaring: "Whatever may have been the voluntary nature of the postal system in the period of its es'ablishment, it is now the main artery through which the business, social, and personal affairs of the people are conducted and upon which depends in a greater degree than upon any other activity of government the promotion of the general welfare." Pike v. Walker, 121 F. (2d) 37, 38-39 (App. D. C. 1941), cert. denicd, 314 U. S. swi (1941), rehearing denied, 314 U. S. xxxvi (1941); 50 Yale L. J. 1479.

116. Att'y Gen. Comm. Ad. Proc., Unitcd States Employes' Compensalion Commission, SeN. DJc. No. 10, Pt. B, 77th Cong., 1st Sess. (1941) 53. 
existing system. The Attorney General's Committee, however, perceived "some measure of inefficiency as well as unfairness both to the Govern; ment . . . and to the Federal employees who lodge the claim."117 The Committee recommended retention of informal methods, including conferences, but wisely declared: "If the conference does not dispose of the case, the dissatisfied employee should be entitled to a hearing . . ."118

A curious wrinkle in the application of the idea of privilege occurs in the Bureau of Marine Inspection and Navigation. ${ }^{110}$ For violations of navigation laws and regulations, statutes provide fines, but the Secretary is given power to "remit or mitigate". The fines originally assessed are always the maximum allowed by statute. Many fines are remitted, and nearly all are mitigated. Thus, fines in one class of case were assessed during one year in the aggregate amount of $\$ 493,235$ but were mitigated to an aggregate of $\$ 75,621$. The remissions and mitigations are determined entirely by informal methods, although de novo judicial review is theoretically available. The idea held by some of the Bureau's officers that in remitting or mitigating they are conferring special favors is mischievous, for in effect the injustice is the same when an officer unfairly refuses to mitigate a $\$ 500$ fine to $\$ 50$ as it is when an officer in the first instance unfairly imposes a fine of $\$ 500$ instead of $\$ 50$. In both cases the question is what amount the violator shall pay; in neither case is the idea of privilege or special favor soundly applicable.

Closely analogous is the problem concerning enemy aliens in the present war. Those found by the Federal Bureau of Investigation to be disloyal are arrested and imprisoned, and then given summary hearings before Enemy Alien Boards, without the right of cross-examination. It is said in justification of denying cross-examination that the Government may imprison all enemy aliens and that hearings are given as a matter of grace to determine, not whether or not the aliens shall be imprisoned, but whether or not they shall be released. Such reasoning is specious. Of course, for practical reasons the Boards which determine whether aliens should be released or imprisoned may well yield to the necessities of the situation and abridge some rights that normally would be accorded. But the question whether or not practical considerations require dispensing with fair procedure should be squarely faced; the idea of privilege should not be allowed to confuse the issue.

In about half the states paroles and conditional pardons may be revoked without opportunity for hearing, and in at least five probation

117. REPORT (1941) 166.

118. Ibid. Other glaring instances of what I regard as unfair treatment of federal employees are the many recent discharges for "subversive" activitics, without opportunity to be heard, and without opportunity to know the nature of findings of the F. B. I. See Gesell and Horsky, Red-Baiting in Washington (1942) 106 NEw Repun. 791.

119. See Att'y Gen. Comm. Ad. Proc., Department of Commerce, Burcau of Marine Inspection and Navigation, Sen. Doc. No. 186, Pt. 10, 76th Cong., 3d Sess. (1941) 24-28. 
may be so revoked. ${ }^{120}$ The decisions often rest upon the conception that the statute or the release itself may reserve the right of summary revocation because the release of the prisoner is a matter of grace. ${ }^{121} \mathrm{~A}$ courageous Circuit Court of Appeals, in the face of an amazing array of cases against it, recently rejected this idea and held that reservation of power to revoke a conditional pardon without opportunity for hearing is a deprivation of due process of law. ${ }^{122}$ Professor Weihofen warmly commends the decision in a keen analysis which explodes the notion that probation, parole and conditional pardon are acts of grace. He concludes: "In short, a chance to be heard before revocation of a conditional release, is from the standpoint of penal administration, good practice, and from the standpoint of the prisoner, a constitutional right." 123

Inspection, Examination and Testing as Substitutes for Hearings. In one class of cases special problems concerning opportunity for hearing arise because hearings are inferior to inspection, examination, or testing. The way to ascertain airworthiness of an airplane or seaworthiness of a vessel or safe condition of a locomotive is for a skilled inspector to look at the object and make his decision. And the same is true of inspecting perishable commodities, quarantining plants, determining the skill of applicants for various kinds of licenses, ascertaining obscenity of a periodical, censoring motion pictures.

The Attorney General's Committee recognizes this:

"The surest way to ascertain what is the grade of grain is for a skilled inspector to test it; the best way to discover whether the radio equipment of a ship is in proper working order is for a radio mechanic to examine it and test it. The soundest procedure in cases of this type is that which recognizes the reality that the inspection or test is and must be the decisive element. Once that is recognized, the improvement of procedure is in the direction of protecting the making of the inspection or test itself, and constantly checking the skill and integrity of the inspector who in this situation is, after all, the adjudicator. Protection, in cases such as these, can be afforded by a right to reexamination or reinspection by another and more experienced inspector, far more than by any right to a formal hearing before an official who must merely listen to testimony."19s

But how do the courts react to a substitution of inspections and tests for hearings? May vital interests of liberty and property be permanently

120. 4 Atr'y Gen. Survey of Rerease Procedudes (1939) 245.

121. Several dozen cases are collected in Weihofen, Recoling Probation, Parole or Pardon Without Hearing (1942) 32 J. CRMr. L. \& Crmmology 531, 532.

122. Fleenor v. Hammond, 116 F. (2d) 982 (C. C. A. 6th, 1941).

123. Weihofen, supra note 121, at 539.

124. REPORT (1941) 37-38. 
altered without giving the affected person a chance to present evidence and argument to the officer who takes the decisive action?

If a general answer is discoverable in the mass of relevant decisions, it is that the administrative determination may usually be made without opportunity for hearing when judicial remedies for improper action remain open or when the court which passes upon the hearing question finds the administrative action proper in the circumstances. Rare are decisions which do not in some way lean on judicial findings. Thts, in the leading North American ${ }^{125}$ case the Supreme Court refused to enjoin the destruction, without opportunity for hearing, of allegedly putrid poultry, but observed: "If a party cannot get his hearing in advance of the seizure and destruction he has the right to have it afterward, which right may be claimed upon the trial in an action brought for the destruction of his property, and in that action those who destroyed it can only successfully defend if the jury shall find the fact of unwholesomeness as claimed by them." 126 The decision does not deny hearing on the question of wholesomeness; it denies administrative hearing in advance of destruction but allows judicial hearing on that question after destruction. The same is true of the leading Copcutt ${ }^{127}$ case, in which the New York Court of Appeals approved summary abatement of dams alleged to be nuisances, for the court was careful to point out that the owner may be protected by injunction or action for damages, and that the defendant board "act at their peril". Even in the muchcited Lawton $v$. Steele, ${ }^{128}$ holding constitutional a summary destruction of fifteen fish-nets worth $\$ 15$ each, ${ }^{120}$ the Court relied not only upon trivial value but also upon the declaration that if the nets were not improperly used the owner "may replevy his nets from the officer seizing them, or if they have been destroyed, may have his action for their value." 130

In all these cases, and others like them, the assumption is that the judicial inquiry after the event will determine the correctness of the administrative action. A substantial body of authority would limit judicial inquiry to the question of the reasonableness of the administrative action, so that the defendant officer in a damages action would not be liable to the plaintiff owner for a reasonable mistake. ${ }^{131}$ But the

125. North Amer. Storage Co. v. Chicago, 211 U. S. 306 (1908).

126. Id. at 316 .

127. People ex rel. Copcutt v. Board of Health, 140 N. Y. 1, 35 N. E. 320 (1893).

128. 152 U. S. 133 (1894).

129. The plaintiff sued for $\$ 525-\$ 35$ for each net.

130. 152 U. S. 133,142 (1894).

131. Raymond v. Fish, 51 Conn. 80 (1883) ; Crayton v. Larabee, 220 N. Y. 493, 110 N. E. 355 (1917). Stason declares: "The trend in the judicial decisions is probably leading away from the imposition of liability upon the officer who acts in good faith but who nevertheless makes a mistake of fact and as a result of such mistake takes action 
reasonableness test seems to crop out only in the damages actions afterwards; in actions to prevent destruction the assumption is uniformly made that the owner's remedy for an improper administrative decision is an action for damages in which inquiry into correctness of the administrative decision will be made. ${ }^{\mathbf{3 2}}$

Other cases approving administrative action without opportunity for hearing are weakened as authorities to the extent that they rest upon a judicial finding or an admission or a lack of challenge of the correctness of the administrative finding. In Ex parte Leciis, ${ }^{133}$ a woman arrested in a house of prostitution was detained in a hospital after medical examination revealed syphilis and gonorrhea. Despite lack of opportunity for hearing, the court denied habeas corpus. This may seem a dangerous precedent - one may be deprived of personal liberty without hearing and in addition be denied the right of habeas corpus. But the case was presented on an agreed statement of facts that the woman was properly detained if the ordinance was valid; she admitted she was diseased. The practical question before the court thus was whether or not to release a woman who admittedly had syphilis and gonorrhea. To hold that one who admits the allegations may be detained without opportunity for hearing is one thing; to hold that one who challenges the allegations may be detained without opportunity for hearing is quite another. The court that decided Ex parte Lewis may quite consistently hold that a petitioner for habeas corpus who denies the disease is entitled either to administrative hearing or to a hearing on habeas corpus which will inquire into the existence of the disease. Ex parte Brown ${ }^{134}$ is in every respect like Ex parte Lexis except that the petitioner for habeas corpus did not specifically admit the disease; however, the petitioner did not deny the disease and limited her case to challenging constitutionality. Failure to deny is the important factor, and the decision is not authority that one who denies the alleged disease may be detained without opportunity for hearing.

outside his powers and causes damage to persons or to private property." See Srasg:z, CASes and Other MAterials ox Amunistritive Tribusills (1937) $539 \mathrm{n}$. Sce Jennings, Tort Liability of Administratize Officts (1937) 21 Mnsw. L. Rev. 203; GeusHORN, op. cit. supra note 76 , at $402-14$.

132. If one could start from scratch, without state constitutional doctrine about sovereign immunity and other legal dogma standing in the way, I think this conclusion might be reached: When the state inspector acting in good faith makes a reasonable mistalse and destroys a steer he wrongly believes to have anthrax, it should be held that the inspector may act without a hearing, that the inspector is not nersenally liable for the mistake, but that the owner may recover the value of the steer from the state. And so of similar cases. For further discussion of reliance on judicial review that is not dc nowo, see infra p. 1137.

133. $328 \mathrm{M}$ o. $843,42 \mathrm{~S}$. W. (2d) 21 (1931).

134. 103 Neb. 540,172 N. W. 522 (1919). 
Many decisions lean on admission, lack of challenge, or judicial finding. ${ }^{135}$ One court allowed destruction of "a musical slot machine" without opportunity for hearing, but pointedly observed that the plaintiff's demurrer had admitted that the machine was a gambling device having no legitimate use. ${ }^{136}$ When the Supreme Court upheld summary destruction of milk from cows not tested for tuberculosis, the plaintiff had admitted his cows were untested, and the Court further stated that plaintiff's "allegation is, not that his cows are free from infectious or contagious disease, but only "so far as he is able to learn or discover'." 197 The Georgia court permitted destruction of liquor without opportunity for hearing but stressed the plaintiff's admission that the amount exceeded the legal limit. ${ }^{138}$ Missouri police seized a "rotary merchandiser" and the court permitted its destruction without hearing, but emphasized that the owner himself in his petition described the machine as a gambling device. ${ }^{130}$ An Ohio decision denied damages for summary destruction of nets, but the plaintiff limited his case to the constitutional question, making no assertion that the nets were being used legally. ${ }^{100}$

135. In addition to those discussed below, see Samuels v. McCurdy, 267 U. S. 188 (1925) ; Hislop v. Rodgers, 54 Ariz. 101, 92 P. (2d) 527 (1939) ; Porter v. Lcwiston, 41 Idaho 324, 238 Pac. 1014 (1925), error dismissed, 270 U. S. 671 (1926); Gray v. Thone, 196 Iowa 532, 194 N. W. 961 (1923); Nelson v. Minneapolis, 112 Minn. 16, 127 N. W. 445 (1910); Lemon v. Rumsey, 108 W. Va. 242, 150 S. E. 725 (1929).

136. Board v. Wagner, 93 Md. 182, 48 Ati. 455 (1901).

137. Adams v. Milwaukee, 228 U. S. 572,583 (1913).

138. Delaney v. Plunkett, 146 Ga. 547, 91 S. E. 561 (1917).

139. State ex rel. Igoe v. Joynt, 341 Mo. 788, 110 S. W. (2d) 737 (1937).

140. State v. French, 71 Ohio St. 186, 73 N. E. 216 (1905). The celebrated Local Government Board v. Arlidge [1915] A. C. 120, is directly in point. The Borough Council issued an order prohibiting use of a house of which Arlidge was lessee's assignce, until rendered fit. On appeal to the Local Government Board, a public inquiry [hcaring] was held before an inspector designated by the Board, but Arlidge did not appear or tender evidence. The Board confirmed the order. Arlidge applied to the council to terminate the order, the council refused, and Arlidge again appealed to the Board, which directed that a second public local inquiry be held before the inspector. Arlidge was present with his solicitor and witnesses. "The respondent's [Arlidge's] solicitor argued his case, and the respondent and his witnesses gave evidence." The inspector submitted his report to the Board, together with a shorthand note of the evidence and speeches. The Board "intimated" to Arlidge that it would be willing to consider any further statement in writing which he desired to submit, but Arlidge did not avail himself of this opportunity. The report of the inspector, who had inspected the premises personally, was not revealed to Arlidge. The Secretary of the Board made affidavit that the Board decided after full consideration of the reports of the inspector, and of the evidence and documents, including observations and objections put forward in correspondence by solicitors of Arlidge. The House of Lords found no violation of "natural justice".

I cannot agree with those who are shocked by the decision, although making the inspector's report available to Arlidge would have been better practice. The unfavorable reception in this country seems to me due in part to misunderstanding. For instance, Dean Pound misstates the case: "The Board had quietly sent an inspector down there to look at the house; the inspector had made a report of the condition in which he found 
State ex rel. McBride a. Supcrior Court ${ }^{141}$ upheld the constitutionality of administrative determination of disputed facts by examination, without opportunity for hearing, even when all judicial review was withdrawn, and even though personal liberty was at stake. The statute provided: "In case of the question arising as to whether or not any person is affected or is sick with a dangerous, contagious or infectious disease, the opinion of the health officer shall prevail until the state board of health can be notified, and then the opinion of the executive officer of the state board of health, or any member or physician he may appoint to examine such case, shall be final."142 After arrest for violating an ordinance, Williams was turned over to the Seattle health commissioner for examination, found to have syphilis, and committed to the city isolation hospital. He appealed to the state board of health, which affirmed. On petition for habeas corpus the lower court appointed three physicians to examine Williams, but the commissioner applied to the Supreme Court for writ of prohibition against further proceedings. The court granted the writ, declaring: "The provision that the finding of the health officers shall be final is a sufficient evidence of legislative intent to leave the whole matter to the health officers without restraint on the part of courts." 143 The result was that Williams was confined, without opportunity for either judicial or administrative hearing, even though he specifically alleged "that he is being held on a pretended claim veratiously instigated by some police officer . . .; that such charge is unfounded and in fact untrue." 144

Whatever the merits of the McBride decision, the result is unusual and probably does not represent the prevailing law. ${ }^{145}$ Still, both pros and cons deserve consideration. The pros: the only fact question presented was whether Williams had syphilis. The best way to find out is by medical examination. The question was not left to uncheclied determination of a single doctor, but the statute provided an appeal to the executive officer of the state board of health or his appointee, presumably a doctor wholly independent of the commissioner. The question is a medical one and doctors' methods - not those of the lawyer - are

it, the local Government Board had looked at the report, and, accepting that report as sufficient, had rejected the appeal." Nowhere in Dean Pound's lengthy statement of the case does it appear that a hearing was held at which Arliuge submitted eridence and his solicitors offered argument, or that the Board considerud the transeript of evidence. Pound, The Growth of Administratize Instice (1924) 2 WIs. L. Kev. 321, 323.

141. 103 Wash. 409, 174 Pac. 973 (1918).

142. Id. at $414-15,174$ Pac. at 975.

143. Id. at $424,174 \mathrm{Pac}$. at 978 .

144. Id. at $411,174 \mathrm{Pac}$ at 974.

145. Wragg v. Griffin, 185 Iowa 243,170 N. W. 400 (1919) holds due process violated by a statute authorizing local boards of healu "upon a suspicion" to examine for venereal disease, but the ground is substantive. 
appropriate. If the safeguard provided by the appeal is insufficient, it may be improved upon, but hearing methods are inappropriate. The cons: a hearing affords protection that a private examination cannot afford - a hearing, by reason of its public nature subjects deciding officers to potential criticism. Arbitrary action is less likely if the officer knows that the record of his decision may be examined by others. To let Williams' own physician make examination, and to require the official doctors to justify their findings before a judge in the presence of Williams' own doctor will assure that clearly improper action will not stand.

Cases like Williams $v$. Smith ${ }^{146}$ are probably of a different stamp. There, an Indiana statute required each state institution to appoint, in addition to its regular physician, two surgeons of recognized ability, to examine the mental and physical condition of "confirmed criminals, idiots, rapists and imbeciles". "If, in the judgment of this committee of experts and the board of managers, procreation is inadvisable and there is no probability of improvement of the mental condition of the inmate, it shall be lawful for the surgeons to perform such operation for the prevention of procreation as shall be decided safest and most effective." The court held the statute unconstitutional, in that "the prisoner has no opportunity to cross-examine the experts who decide that this operation should be performed upon him. He has no chance to bring experts to show that it should not be performed; nor has he a chance to controvert the scientific question that he is of a class designated in the statute." 147 The decision is sound. The administrative determination requires far more than mere physical examination to find presence or absence of disease or deficiency; it entails exercise of broad discretion involving not only controversial scientific questions but also ethical problems on which reasonable minds may differ. And the method of hearing is practically well suited to the determination. ${ }^{148}$

The decisions in the inspection, examination and testing cases, considered broadly, withstand successfully a critical study. The courts

146. 190 Ind. 526,131 N.E. 2 (1921); and see In re Opinion of the Justices, 230 Ala. 543,162 So. 123 (1935).

147. 190 Ind. 526, 527, 131 N. E. 2.

148. Paducah v. Hook Amusement Co., 257 Ky. 19, 77 S. W. (2d) 383 (1934), held unconstitutional summary destruction of equipment used for dance marathons. Although the court's reasoning is based on procedural due process, one may conjecture that substantive aspects of the ordinance were influential. The same may be said of McConnell v. McKillip, 71 Neb. 712,99 N. W. 505 (1904), holding unconstitutional a statute allowing game wardens to seize summarily equipment used in hunting withott a licensc. One of the most extreme cases I have seen is People v. Marquis, 291 Ill. 121, 125 N. E. 757 (1920), holding unconstitutional the confiscation of a truck used for hauling liquor, on the ground the statute failed to provide hearing for the owner, even though the owner was in fact given a hearing and the driver was tried and convicted. Compare GoldsmithGrant Co. v. United States, 254 U. S. 505 (1921). 
permit - even encourage - administrative action to be taken on the basis of inspection, examination, or testing without opportunity for hearing, but the judges nevertheless provide in nearly all cases some sort of judicial remedy or judicial assurance against arbitrary action. The net effect is that probably well over ninety per cent - perhaps more than ninety-nine per cent - of the fact questions presented are determined finally by direct methods, keeping judicial methods in reserve for extreme cases. The only troublesome question raised is whether or not in a situation such as that in the $M c B$ ride case opportunity for judicial determination may be cut off.

Despite the awkwardness of judicial methods for these cases, it is hard to quarrel with retention of the reserve power in the judges. Certainly the potentiality of judicial hearing afterwards does not in practice impair efficiency of the system taken as a whole. Usually the party adversely affected by the results of an inspection or examination is satisfied with the findings and does not request a hearing. Although gradings of grain are by statute only prima facie evidence in court, the gradings have not been questioned in court in 23 years. ${ }^{143}$ Of thousands of inspections of vessels since 1838 when the work of inspecting began, no trace of appeal to court can be found. Bar examiners determine questions of fact-qualifications of applicants - by written examinations, and inclination to challenge examiners' conclusions is wholly absent. District inspectors for the ICC inspected 105,000 locomotives last year, finding 37,000 defects on 9,570, and ordering 560 out of service; $;^{150}$ although appeals are allowed from inspector to Director and from Director to Commission, in twenty years seven appeals have been taken to the Director and none to the Commission. ${ }^{151}$ If these figures are at all representative, administrative methods are highly satisfactory; at worst, the potentiality of judicial hearing can do no harm. Yet it may correct occasional injustices, and its availability undoubtedly has a salutary effect upon administrative officials.

Emergency and Temporary Action. The Emergency Price Control Act of 1942 provides: "Whenever in the judgment of the Administrator such action is necessary . . . he may, without regard to the foregoing provisions of this subsection [prescribing procedures] issue temporary regulations or orders establishing as a maximum price . . . the price . . . prevailing . . . five days prior to the date of issuance of such temporary regulations or orders; but such temporary regulation or

149. REPORT (1941) 36.

150. ICC ANN. REP. (1941) 95.

151. Atty Gen. Comm. Ad. Proc, Interstate Commerce Commission, SEr. Doe. No. 10, Pt. 14, 77th Cong., 1st Sess. (19+1) 93. 
order shall be effective for not more than sixty days. . . ."152 Here is an authorization for administrative action which may drastically affect vital interests not only without hearing but also without even so much as consultation with an industry advisory committee. Of course, emergency is complete justification. When the building is burning or contagion is spreading or putrid poultry is about to be sold, action must be immediate, leaving adjustment of rights for a later day.

The Interstate Commerce Act prohibits changes in rates or fares except after 30 days' notice, but gives the Commission power to make exceptions to the notice requirement. ${ }^{153}$ Last year 9,155 applications requested permission to establish rates or fares on less than 30 days' notice or waiver of tariff-publishing rules; specific orders granted 8,722 and denied $433 .{ }^{154}$ The average time from receipt of application until dispatch of the order is approximately three days. ${ }^{155}$ Obviously, formality must yield; nevertheless conferences or quick informal hearings are not unknown in exceptional cases.

The Securities Act makes registration statements effective twenty days after filing. Examination of a registration statement normally consumes about ten days. If a deficiency is discovered concerning which a dispute arises, and if the registrant is to avoid the possibly disastrous institution of a stop order proceeding, the dispute must be settled by hasty methods providing protection far short of hearing. A registrant dissatisfied with a deficiency letter may only confer with the Commission or its representatives. Then, when the registrant files an amendment, the twenty-day period begins again unless the Commission consents to acceleration. "The question of acceleration is often of considerable moment to the registrant." 158 Yet, except in rare instances, acceleration questions have been determined without even so much as conferences. Exigencies of the twenty-day provision must in practice be the root of all answers to procedure questions.

One might go on through the agencies and tabulate innumerable instances of necessity for immediate action, where haste must supplant other considerations. Thus, temporary action pending full hearing is often appropriate in licensing. Many licenses are designed to provide control over licensees for the protection of the public. When the agency learns that a licensee is engaging in practices dangerous to the public, it might be required to provide opportunity for hearing before acting, for the licensee's interest is normally strongly on the side of requiring

152. Pub. L. 421, 77th Cong., 2d Sess. (Jan. 30, 1942), §2(a).

153. 41 Stat. 483 (1920), 49 U. S. C. §6(3) (1940).

154. ICC ANn. Rep. (1941) 134.

155. Att'y Gen. Comm. Ad. Proc., Interstate Commerce Commission, SEN. Doc. No. 10, Pt. 11, 77th Cong., 1st Sess. (1941) 44-45.

156. Att'y Gen. Comm. Ad. Proc., Securities \& Exchange Commission, Sen. Doc. No. 10, Pt. 13, 77th Cong., 1st Sess. (1941) 26. 
a procedure which includes full safeguards before the licensee can be adjudged guilty of unlawful conduct. Sometimes, of course, the peril may be so pressing that the license should be suspended pending hearing on the question of revocation or restoration. The clearest case permitting this is Halsey, Stuart \& Co. v. Public Service Commission. ${ }^{157}$ Plaintiff for twenty years had dealt in securities, doing a business in IVisconsin of twelve to nineteen million dollars per year. The Commission, pursuant to statutory authority, on its own motion and without prior opportunity for hearing, suspended plaintiff's broker's license, on the ground that officers of the company had been indicted for using the mails to defraud. Plaintiff sought an injunction on the ground of unconstitutionality of suspension without opportunity for hearing. The court upheld the order.

Even the power of suspension, however, need not be exercised without safeguards. Hasty informal hearings or conferences should in some circumstances precede the issuance of the suspension order, especially when important interests may be adversely affected. A professional man may suffer irreparable injury from a suspension order improvidently issued.

The ICC and other rate-fixing agencies have authority to suspend newly filed rates and simultaneously order a hearing. ${ }^{15 s}$ The Communications Commission in its telephone and telegraph regulation may suspend "any new charge, classification, regulation, or practice."163 The period of suspension varies; for the ICC it is longest - seven months. Interests of some magnitude may hinge on the decision whether or not to suspend. Last year the ICC suspended 785 rates and refused to suspend 619.160 About ninety-five per cent of all suspensions are made upon protest, the others being on the Commission's own motion. Most protests are made by telegram, and the Commission, as a safeguard, always notifies the carrier by telegram of the receipt of protests, summarizing the contentions advanced. In about twenty per cent of the cases conferences are held on the question of suspension. ${ }^{101}$

157. 212 Wis. 184,248 N. W. 458 (1933). For federal statutes allowing suspending licenses pending hearing, see Food \& Drug, 52 Stat. 1048 (1938), 21 U. S. C. \$34t(b) (1940); Motor Carrier, 49 Stat. 555 (1935), amended 52 Stat. 1238 (193S), 49 U. S. C. $\S 312$ (a) (1940), amended 54 Stat. 924 (1940), 49 U. S. C. $\$ 312($ a) (1940); Civil Aeronautics, 52 StAT. 1011 (1938), 49 U. S. C. $\$ 559$ (1940).

158. CAA, 52 Stat. 1018 (193\$), 49 U. S. C. $\$ 642(\mathrm{~g})$ (1940) ; Federal Power Commission, 49 Stat. 851 (1935), 16 U. S. C. \$\$24(d) (1940); ICC, Railreads, 41 SтAт. $486(1920), 49$ U. S. C. $\$ 15(7)(1940)$, as amended 54 St.sT. 912 (1940), 49 U. S. C. $\$ 15(7)$ (Supp. 1941); ICC, Motor Carriers, 49 ST.IT. 558 (1935), 49 U. S. C. $\$ 316(\mathrm{~g})$ (1940), as amended 54 Star. $924(1940), 49$ U. S. C. $\$ 316(\mathrm{~g})$ (1940); ICC, Water Carriers, 54 Stat. 937 (1940), 49 U. S. C. $\$ 907$ (g) (Supp. 1941).

159. FCC, $4 \$$ StAT. 1071 (1934), 47 U. S. C. $\$ 204$ (1940).

160. ICC ANn. Rep. (1941) 135.

161. Att'y Gen. Comm. Ad. Proce, Intersiate Commere Commission, SE:i. Doc. No. 10, Pt. 11, 77th Cong., 1st Sess. (1941) 49-51. 
A typical decision illustrates what is involved in suspension cases. In M. C. Kiser Co.v. Central Georgia Railway, ${ }^{162}$ complainants were wholesale dealers in boots and shoes in Atlanta, purchasing from Boston, Providence and New York, and paying for water and rail transportation at 95 cents per 100 pounds, the rate approved by the ICC after "two or three different hearings". The carriers filed a new rate of $\$ 1.14$ and $\$ 1.19$. Complainants had made extensive investments and contracts for both purchase and sale of shoes in reliance upon contint1ance of the old rates. The new rates would impose an additional freight burden of approximately $\$ 15,000$ during one season. Complainants protested the new rates and requested suspension, but after "informal hearing" (conferences) the Commission declined to suspend. Complainants sought an injunction against changing the rates without full hearing and without a determination of the reasonableness of the new rates. The District Court granted a temporary restraining order but on full consideration dissolved it and denied injunction; the Circuit Court of Appeals affirmed. The question whether or not the newly filed rates shall be suspended during the period pending full hearing is for the Commission alone to decide, on the basis of informal hearings or conferences, and the courts will not interfere. ${ }^{103}$

It seems a short jump from the long-approved, widely-used stuspension power to a power to fix temporary rates pending more permanent orders issued after full hearings. Mr. Justice Black has collected horrible examples of rate cases consuming years ${ }^{164}$ - one beginning in 1921 and not yet ended in 1937. ${ }^{165}$ Need for temporary rate-fixing; in the face of such experience, is obvious. The Supreme Court once was coldly unsympathetic: "They were final legislative acts as to the period during which they should remain in effect pending final determination; and if the rates prescribed were confiscatory the Company would be deprived of a reasonable return upon its property during such period, without remedy, unless their enforcement should be enjoined." The Court accordingly affirmed an injunction against temporary rates, even though the injunction rested solely on pleadings and affidavits. ${ }^{100}$

In Wisconsin Telephone Co. v. Public Service Commission, ${ }^{\mathbf{1 0 7}}$ the court struck down a temporary rate order issued pursuant to a statute providing: "The Commission is empowered to issue conditional, temporary, emergency and supplemental orders." The court said this pro-

162. 236 Fed. 573 (S. D. Ga. 1916), aff'd, 239 Fed. 718 (C. C. A. 5th, 1917).

163. For further authority upholding suspension, see Manhattan Transit Co. v. United States, 24 F. Supp. 174, 177 (D. Mass. 1938), collecting cases.

164. McCart v. Indianapolis Water Co., 302 U. S. 419, 435 (1938).

165. Ohio Bell Tel. Co. v. Public Utilities Comm., 301 U. S. 292 (1937).

166. Prendergast v. New York Telephone Co., 262 U. S. 43 (1923).

167. 232 Wis. 274, 287 N. W. 122 (1939), cert. denied, 309 U. S. 657 (1940). 
vision was subject to procedural requirements of other parts of the statute, and further declared: "The Legislature certainly never intended to authorize the Commission to issue orders affecting the rights of citizens without opportunity to be heard. A legislative act purporting to confer such power would be clearly invalid." Yet the reasons advanced by the Commission in support of its temporary order seem exceedingly persuasive. The temporary order in question was issued after 35 months of investigation, when the record comprised 7,721 pages of testimony and 428 exhibits; the Commission had concluded accounting and engineering phases of its case, and the Company had cross-examined but had introduced only a slight part of its affirmative evidence. "It would seem to us to be a stultification of the State's regulatory power if, realizing that this case has already gone on for three years and may endure for a fourth, we should in the meantime be hamstrung and powerless to protect the public against rates which, based upon the evidence before us, are unreasonably high. Particularly is this consideration reinforced at the present time by the Commission's engineering appraisal . . . which . . . demonstrates . . . that the rate base herein determined, is conservative . . We are forced to conclude that we would be remiss in our duty if we did not issue a further temporary order at this time. To assert to the contrary and hold that we should have to go through the exhaustive process of hearings until every bit of direct and redirect, cross and recross, rebuttal and sur-rebuttal, has been completely introduced, sifted and argued down to the last decimal before even a temporary order may be issued, is to declare that . . . the statutes in the various states for temporary orders are meaningless and null." 168

The Supreme Court in 1942 sustained an interim order of the Federal Power Commission, issued after extensive hearings but before their completion, based upon the companies' statement of book cost, their estimate of value of physical property, and their estimate of prospective income: "The companies cannot complain that they were denied a full hearing because they had not been able to examine or redirect their own witnesses who had not been cross-examined, or because they had no opportunity to cross-examine or rebut witnesses who were not offered by the Commission. The right to a full hearing before any tribunal does not include the right to challenge or rely on evidence not offered or considered." 169

Another promising temporary-rate development is the enactment of statutes permitting recoupment from losses accruing from temporary rates later adjudged too low. This system is glowingly described by Mr.

168. Id, at $296,287 \mathrm{~N}$. W. at 134 .

169. Fẹeral Power Comm. v. Natural Gas Pipeline Co., 62 Sup. Ct. 736 (U. S. 1942). 
Justice Frankfurter in a concurring opinion: "The statute . . . is a conscientious and informed endeavor to meet difficulties engendered by legal doctrines which have been widely rejected by the great weight of economic opinion, by authoritative legislative investigations, by utility commissions throughout the country, and by impressive judicial dissents. As a result of this long process of experience and reflection, the two states in which titilities play the biggest financial part - New York and Pennsylvania - have evolved the so-called recoupment scheme for temporary rate-fixing (thereby avoiding some of the most wasteful aspects of rate litigation) as a fair means of accommodating public and private interests. It is a carefully guarded device for securing 'a judgment from experience as against a judgment from speculation' . . . in dealing with a problem of such elusive economic complexity as the determination of what return will be sufficient to attract capital . . . and at the same time be fair to the public..."170

\section{Limitation of Requirement of Opportunity to Be Heard to One Stage} of Entire Proceeding. Due process requirements are satisfied if at any time before governmental action becomes final hearings are allowed either by administrative or by judicial action. We have already observed numerous cases - particularly those relating to privilege and inspection - which uphold administrative action on the ground that judicial review supplies administrative deficiencies. This doctrine is widely accepted. ${ }^{171}$ In the leading Hagar case, ${ }^{172}$ the Court rejected a contention that due process was violated by levying swamp reclamation assessments without opportunity to be heard, observing that collection could be made only through court proceedings and that the requirements "are all satisfied where a hearing in court is thus allowed." The Supreme Court has stated the guiding principle: "It is enough that all available defenses may be presented to a competent tribunal before exaction of the tax

170. Driscoll v. Edison Light \& Power Co., 307 U. S. 104, 123-24 (1939). The Pent1sylvania recoupment statute requires "reasonable notice and hearing"; it is a way of avoiding the full and protracted hearing familiar when the doctrine of Smyth v. Ames, 169 U. S. 466 (1898) is applied, not a way of avoiding hearing altogether on the temporary rates. Of course, on the requirements of Smyth v. Ames, Federal Power Commission v. Natural Gas Pipeline Co., 62 Sup. Ct. 736 (U. S. 1942) must be considered. See Comments (1937) Temporary Utility Rates, 46 YALE L. J. 505; (1939) 87 U. of PA. L. Rev. 456; Note (1942) 51 YaLE L. J. 1027; Fisher, Rate Regulation-Validity of Temporary Rate Order (1939) 38 Mic․ L. Rev. 72.

171. Nickey v. Mississippi, 292 U. S. 393 (1934); Phillips v. Commissioner, 283 U. S. 589 (1931); Belcher v. Farrar, 8 Allen 325 (Mass. 1864); Commonwealth v. Hargis Bank \& Trust Co., $233 \mathrm{Ky} .801,26 \mathrm{~S}$. W. (2d) 1045 (1930). That the same principle applies to judicial action, see American Surety Co. v. Baldwin, 287 U. S. 156 (1932).

172. 111 U. S. 701 (1884). 
and before the command of the state to pay it becomes final and irrevocable." 173

But when the review is not de novo, are requirements satisfied? A recent tax case held that review limited to determining whether overvaluation was willful does not remedy the earlier failure to provide opportunity for hearing on the question whether the valuation was merely excessive. ${ }^{174}$ But in Bourjois $v$. Chapman ${ }^{175}$ the Supreme Court held due process satisfied by the following review provision: "From the refusal ... to issue a certificate of registration . . . appeal shall lie to the superior court." The Court did not bother to inquire whether. this provision might be interpreted as permitting only a determination whether the findings are supported by substantial evidence. Indeed, the Supreme Court has even held that availability of judicial review through injunction proceedings satisfies due process requirements. ${ }^{178}$

Especially revealing is Southern Railway $v$. Virginia. ${ }^{177}$ The state highway commissioner ordered elimination of a grade crossing without allowing the railroad to be heard on the question whether the elimination should be ordered. The statute did not provide for judicial review, but the state court had declared: "Should the power vested in the Highway Commissioner be arbitrarily exercised, equity's long arm will stay his hand." 178 The majority of the Supreme Court held this insufficient: "The infirmities of the enactment are not relieved by an indefinite right of review in respect of some action spoken of as arbitrary." 179 Three justices dissented on the ground that the power "may be exercised without notice or a hearing . . provided adequate opportunity is afforded for review in the event that the power is perverted or abused; and that such opportunity has been given by the statutes of Virginia as construed by its highest court." The dissenters would thus uphold the action even though at neither administrative nor judicial stage is opportunity given for hearing on the merits. ${ }^{180}$

Lack of opportunity to be heard preceding administrative decision may be remedied by administrative review. Thus, a board of revision of tax

173. Nickey v. Mississippi, 292 U. S. 393,396 (1934).

174. Orcutt v. Crawford, 85 F. (2d) 146 (C. C. A. 10th, 1936).

175. 301 U. S. 183 (1937).

176. Security Trust and Safety Vault Co. v. Lexington, 203 U. S. 323, 333 (1900): "Whether the opportunity to be heard which has been afforded to the plaintiff has been pursuant to the provisions of some statute ... or by the holding of the court that the plaintiff has such right in the trial of a suit to enjoin the collection of the tas: is nut material."

177. 290 U. S. 190 (1933).

178. Southern Railway v. Commonwealth, 159 Va. 779, 794, 167 S. E. 578,582 (1933).

179. 290 U. S. $190,199$.

180. The dissenters were Hughes, C. J., Stone and Cardozo, JJ. In predicting what the present Court would do, I think much weight should be given to the fact that MIr. Justice Brandeis was with the majority. 
assessments may by giving opportunity for hearing make up for the lack of such opportunity preceding the assessment. ${ }^{181}$ When it was contended that an industry committee of the Wage and Hour Administration had unconstitutionally failed to allow opportunity for hearing, the Court rejected the contention on the ground that proceedings before the Administrator satisfy the requirements of due process. ${ }^{182}$ In United States $v$. Illinois Central Ry., ${ }^{183}$ the ICC specifically refused a hearing before entering an order fixing certain rates. The Supreme Court held that an injunction against enforcement of the rates should be refused on the ground that under the statute the Commission may properly issue the order in the first instance without hearing if it will allow hearing upon complaint after issuing the order but before it becomes effective: "Without attempting to lay down any general rule, but confining ourselves to the statute and case in hand, we accordingly hold that it was not essential, under the due process of law clause, that a hearing should be accorded in advance of the initiating order. It is enough that opportunity was given for a full and fair hearing before the order became operative." 184

This principle was not acceptable to a lower federal court. The National Bituminous Coal Commission, without prior hearing, prescribed minimum prices, on the theory that the statutory requirement of hearing could be satisfied by permitting the filing of petitions and holding hearings thereon before the effective date of the price order. Despite statutory provisions which might easily have been interpreted as consistent with this theory, and despite the Illinois Central precedent, the court enjoined the order, even though the complaining parties had not first pursued the administrative remedy available to them. ${ }^{185}$

181. Palmer v. McMahon, 133 U. S. 660 (1890). In McGregor v. Hogan, 263 U. S. 234 (1923), where a Board increased valuation of property for tax purposes, without opportunity for hearing, the Court rejected a contention that due process requirements were violated, because the taxpayer had opportunity to demand arbitration. But $\mathrm{cf}$. Turner v. Wade, 254 U. S. 64 (1920).

182. Opp Cotton Mills, Inc. v. Administrator of Wage and Hour Division, 312 U. S. 126 (1941). See also Louisville \& N. R. R. v. United States, 10 F. Supp. 185 (N. D. III.) (1934). The principle works both forwards and backwards. Thus, where hearing was given before assessment, it was held that none to correct errors afterwards was required. Pittsburgh, Cinn., Ch. \& St. L. Ry. v. Backus, 154 U. S. 421,426 (1894). A different application of the same principle is found in The New England Divisions Casc, 261 U. S. 184 (1923), approving the use of typical evidence to support a general order, relying on the idea that more accurate evidence may be used in future specific cases.

183. 291 U. S. 457 (1934), 43 Y ALE L. J. 1300. Justices Brandeis, Stone, Roberts, and Cardozo, concurring specially, would have disposed of the case on the ground that the respondents had filed with the Commission no complaint designed to secure a hearing.

184. 291 U. S. 457,463 (1934).

185. Saxton Coal Mining Co. v. National Bit. Coal Comm., 96 F. (2d) 517 (App. D. C. 1938) ; see Comment (1938) 6 Geo. Wash. L. Rev. 477. 50 Stat. 72 (1937), 15 U. S. C. $\$ 829$ (Supp. 1941) requires opportunity to be heard for every "order which is 
Some administrative regulations have full force and effect of law; others, like the Treasury tax regulations, are merely interpretative and purport to do no more than guide administrative adjudication. ${ }^{180} \mathrm{Com}$ plete judicial review is available, the theory being that the reviewing court is in no way bound to follow the regulations. Therefore, the prevailing practice of issuing such interpretative regulations without providing opportunity to be heard can violate no constitutional requirements. But the wisdom of denying opportunity to participate in formulation of interpretative regulations is not so clear. Interpretative regulations are often decisive of cases. Courts lean heavily upun them. ${ }^{18 T}$ And the Supreme Court has even declared that reenactment of a statute means that "Congress must be taken to have approved the administrative construction and thereby to have given it the force of law."1ss From a practical standpoint, the theoretical availability of complete judicial review does not prevent interpretative regulations from having permanent substantive effect, and although hearings are not feasible, all opportunity for participation in formulation of regulations ought not to be denied. ${ }^{189}$

Even though due process may be satisfied by judicial review, it does not follow that judicial review is an adequate substitute for administrative hearings when these are the best practical means of finding facts. Indeed, from the standpoint of both efficient administration and adequate safeguards for private interests, the advantages of administrative rather than judicial hearings are frequently patent. For protection of private parties, a regularized administrative procedure may afford far better safeguards than a theoretical right of review, which is so often illusory. If the amount involved is small, if the hardship of appealing to a court is great, ${ }^{130}$ if the court will be strongly influenced by the agency's view,

subject to judicial review." The provision for review contains nothing to prevent application of the usual doctrine requiring exhaustion of administrative remedies. The court might therefore properly have held that a general order subject to administrative attacl: before its effectiveness is not an order which is subject to review, and that the statute therefore does not require opportunity to be heard prior to the original order. And constitutional objections could be met by applying precisely the technique of the Illiwois Central case.

186. See Lee, Legislative and Interpretive Regulations (1940) 29 GEo. L. I. 1.

187. E.g., Houston v. St. Louis Ind. Packing Co., 249 U. S. 479 (1919).

18S. Helvering v. R. J. Reynolds Tobacco Co., 306 U. S. 110, 115 (1939). But of. Helvering v. Wilshire Oil Co., Inc, 308 U. S. 90, 100-01 (1939).

189. Att'y Gen. Comm. Ad. Proc, Adninistration of Intcrnal Reacnue Lares, SEr. Doc. No. 10, Pt. 9, 77th Cong., 1st Sess. (1941) 64-65.

190. A good example of hardship in appealing to a court is Jaclison v. Bell, 143 Tenn. 452, 226 S. IV. 207 (1920), where the owner of a building condemned by a fire commissioner could go to court only by posting bond for court costs and "all damages that may" be occasioned on account of the failure of such owner or occupant to comply with the order . . ." Sheer expense or inconvenience of a judicial proceeding may often in a practical sense defeat the opportunity for judicial review. 
if in spite of the theoretical scope of review the practical inquiry is into reasonableness rather than rightness, if only the exceptional case can go to court - if for any reason the administrative decision importantly affects the final outcome - safeguards at the administrative stage should be preferred to the safeguards provided by judicial review. ${ }^{101}$

\section{Conclusions}

The solution of the problem of determining when to require opportunity to be heard in the administrative, process lies in discovering the best practical means in the varying circumstances for assuring enlightened administrative action which will protect those affected by considering their evidence and their argument and by letting them stubject to their testing processes the materials on which the agency acts. Methods other than hearings are often most effective for this purpose; private interests frequently may be best protected by such methods as interviews, conferences, questionnaires, submission of tentative orders or regulations for written comments, collaboration between agency representatives and private representatives in drafting rules, consultation of agency officials with advisory groups which represent private parties, reception of written evidence and argument without an oral process. Sometimes two or more of these informal processes should be combined.

Judicial decisions which grapple with this problem are regrettably deficient in their frequent failure to give adequate recognition to the alternative devices that may be superior to hearings.

A speech-making or public-meeting type of hearing sometimes affords the most efficient way for the agency to safeguard private rights and develop the necessary information and understanding, either with or without informal processes; a hearing resembling a legislative committee investigation is often preferable to a trial. A trial is appropriate when a dispute arises about adjudicative facts, that is, facts which peculiarly relate to particular parties, their past conduct, or their circumstances,

191. One who has not read the decisions on opportunity to be heard would naturally expect the question of due process to be whether or not the required opportunity has been given, not whether a statute provides or fails to provide the opportunity. The expectation in my opinion would be thoroughly sound. But the view to the contrary, although probably on the wane, has considerable vitality. E.g.: "If the statute did not provide for a notice in any form, it is not material that as a matter of grace or favor notice may have been given of the proposed assessment. It is not what notice, uncalled for by the statute, the taxpayer may have received in a particular case that is material, but the question is, whether any notice is provided for by the statute." Security Trust Co. v. Lexington, 203 U. S. 323, 333 (1906). For the more enlightened view to the contrary, see Bourjois v. Chapman, 301 U. S. 183, 188 (1937). Professor Gellhorn traces the historical development and analyzes the cases with his usual masterful skill in Geuluons, op. cit. supra note 76 , at 451-60. 
business or property. Economic, financial and statistical facts of a general character, not limited to particular parties, usually may be better developed without following courtroom methods. A tendency in some quarters to require a trial to resolve questions of interpretation or law or policy, when no specific facts are disputed and no conflicting evidence is introduced, leads to avoidable inefficiency and serves no useful purpose. Cross-examination by adversaries is an excellent device for testing proof, but it is not a proper vehicle for persuasion. Despite some sweening judicial generalizations that fixing rates and wages and prices requires the trial technique, I think that one must inquire into the lind of materials needed, and their sources, before deciding how to go about getting those materials, and examination of specific price-fixing functions reveals that trial methods are sometimes inferior to other methods for protecting private interests and securing the requisite information and understanding for wise price regulation. Such devices as the ICC shortened and modified procedures are of vast significance and their further development and more extensive use should be encouraged.

The dogma and conceptualism which plague this subject too often lead unsuspecting judges to unjust decisions. Many opinions revolve around separation-of-powers labels, although the labels probably play a smaller part in judicial motivation than in opinion writing. Realism requires recognition that a function may be somewhat judicial and somewhat legislative and neither wholly one nor wholly the other, and that a function need not necessarily be classified the same way for all purposes. The more discerning courts decide on the basis of the desirable procedures what label to attach, not on the basis of the label what procedure to require.

The oft-repeated notion that an agency may perform a function without a hearing if the legislature could perform the same function without a hearing is unsound in that it ignores vital differences between agency and legislature. Agencies whose members represent constituencies are exceptional.

The major premise of some decisions that hearings are not feasible when the number of affected parties is large is unsupported by experience. The true test for the appropriateness of a trial is not the number of parties but whether the controversy relates to facts which concern individual parties. When adjudicative facts are disputed, trial methods are desirable irrespective of the number of parties. Even when the needed information is general, or when the problem is one of policy or discretion or law, a large number of parties does not justify denying all opportunity to reach the eyes and ears of the deciding agency.

The doctrine that privileges may be taken away or adversely affected without giving their holders opportunity to be heard on disputed adjudicative facts is pernicious. To allow administrative officers summarily 
to destroy a profitable business when adjudicative facts are denied is unsound government. A procedure which is unfair for inflicting a penalty is not rendered fair by using it to withdraw a benefit. Happily, the pervasive judicial indulgence in conceptualism about privileges is largely limited to language and is decisive of relatively few cases.

When direct observation rather than hearing is the most reliable method for finding facts, courts permit agencies to decide without hearing; with few exceptions, however, full judicial remedies for improper administrative action are made available. The resulting system seems satisfactory, for judicial hearings are held in reserve for correction of possible abuses but in practice hearings are held in a negligible portion of the cases.

Although emergency action without previous hearing is sometimes appropriate, safeguards usually may still be provided through informal methods for hasty participation by parties. Too little developed is the idea of temporary action pending hearing, for failure to act until protracted hearings are completed is often the equivalent of an adjudication in favor of those who advocate continuing the status quo for the period of the hearing, without giving their opponents an opportunity to be heard. Of course, when important rights are involved, temporary action should inot be taken without providing such informal safeguards as circumstances permit.

The prevailing judicial doctrine is that improper denial of administrative hearing may be remedied by availability of judicial review of sufficient scope, but widespread reliance upon this doctrine is unfortunate. Safeguards at the administrative stage are clearly superior to safeguards by a theoretical right of review which in practice is often illusory. 